\title{
Modalidades y productos de juego de la Organización Nacional de Ciegos Españoles
}

\author{
Juan Francisco Pérez Gálvez \\ Profesor Titular de Derecho Administrativo \\ Universidad de Almería
}

Sumario: I. La Organización Nacional de Ciegos Españoles tiene reconocida legalmente una concesión estatal en materia de juego que se justifica por el interés general de sus fines sociales. 1. Régimen jurídico. 2. Fuentes de financiación y modalidades de juego autorizadas. 2.1. Fuentes de financiación. 2.2. Modalidades de juego autorizadas. 2.2.1. Modalidad cupón prociegos. 2.2.2. Modalidad lotería instantánea o presorteada. 2.2.3. Modalidad juego activo. 2.2.4. Otras que puedan autorizarse en el futuro. II. El cupón o boleto. 1. Concepto. 2. Naturaleza jurídica. 3. Clasificación. 3.1. Reformas del cupón y otras modalidades de juego que han determinado su modificación. 3.1.1. La década de los 80 y los 90. 3.1.2. La reforma de comienzos del siglo XXI. 3.2. Lotería instantánea o presorteada y lotería condicionada a la realización del sorteo. 3.3. Tipos de soporte de comercialización: preimpresos, emitidos por terminales de punto de venta, emitidos por cualquier otro soporte electrónico o telemático, emitidos en cualquier otro soporte o procedimiento que se ajuste a la norma aplicable en vigor, o que se autorice en el futuro. 3.4. Formas de comercialización: para un único sorteo o para varios sorteos. 3.5. Modalidades de comercialización: productos de juego. 3.5.1. El cupón de la ONCE. A. Sorteo del cupón de lunes a jueves. B. Sorteo del cupón de los viernes (cuponazo), con un premio especial a un solo cupón de 6.000.000 de euros. C. Sorteo del cupón de "Fin de Semana". D. Abono semanal: bono-cupón. E. Otras formas de participación en varios productos o sorteos de un mismo producto distintos del abono semanal. 3.5.2. Lotería instantánea de boletos de la ONCE: rasca y gana, siete de la suerte, tres de seis cantidades, tres en raya a un euro y tres en raya a dos euros. 3.5.3. Juego activo y su producto denominado "El Combo". A. Su origen: la Resolución de la Secretaría de Estado de Servicios Sociales, Familias y Discapacidad de 29 de junio de 2004. B. Reglamento regulador del juego activo denominado "El Combo". 4. Elementos. 4.1. El documento o título. 4.1.1. Tipo de soporte y formas de comercialización. 4.1.2. Contenido de la impresión. A. Anverso. B. 
Reverso. C. Cupones o boletos emitidos por terminal de punto de venta. 4.2. Las series. 4.3. Precio y estructura de premios. 4.4. El sorteo. 4.5. Derechos de los compradores. 4.5.1. ¿Cómo garantizar los derechos de los consumidores?. 4.5.2. Reclamaciones y recursos. 5. Grupo normativo regulador. 5.1. Evolución legislativa. 5.2. Una innovación muy reciente: los textos refundidos de los reglamentos reguladores de las distintas modalidades y productos de juego de la ONCE. 5.3. La autorización del sorteo del cupón pro-ciegos y de la gestión de otros juegos de azar que explota la ONCE. 5.3.1. Concesión estatal del cupón prociegos. 5.3.2. Marco normativo de la autorización de otras modalidades de juego. 5.3.3. Régimen jurídico del proceso de autorización. 6. Cuota de participación del cupón en el juego. 7. Publicidad. 8. Los juegos de la ONCE contribuyen decisivamente a la generación de empleo y recursos. 8.1. El epicentro del sistema. 8.2. Distribución de recursos. III. La venta de las modalidades y productos de juego. 1. Concepto. 2. Naturaleza jurídica. 3. Clasificación. 3.1. En virtud de quien realiza la venta. 3.2. En virtud de la modalidad de venta: fija e itinerante. 3.3. En virtud de la tipología de los puntos o zonas de venta. 3.3.1. Puesto de venta.3.3.2. Área de venta. 3.3.3. Quiosco. 3.3.4. Stand. 3.3.5. Local comercial. 3.3.6. Ruta de venta. 3.4. En virtud del instrumento utilizado para participar en el sorteo: compra de un cupón/boleto o una transacción electrónica a través de terminales móviles con comunicaciones inalámbricas. 4. Asignación y control del punto o zona de venta. 4.1. Asignación. 4.2. Control. 4.2.1. Carné de vendedor. 4.2.2. Aplicación informática. 5. Creación de puntos de venta fijos para la comercialización de los juegos: quioscos y stands. 5.1. Requisitos para la instalación de quioscos y stands. 5.2. Estudios para el análisis y creación de puntos o zonas de venta. 6 . La ubicación de puntos de venta fijos (quioscos de la ONCE) en el dominio público. 7. La ubicación de puntos de venta fijos en centros comerciales.

\section{LA ORGANIZACIÓN NACIONAL DE CIEGOS ESPAÑOLES TIE- NE RECONOCIDA LEGALMENTE UNA CONCESIÓN ESTATAL EN MATERIA DE JUEGO QUE SE JUSTIFICA POR EL INTERÉS GENERAL DE SUS FINES SOCIALES.}

\section{Régimen jurídico.}

La ONCE es una Corporación de Derecho Público, de carácter social, sin ánimo de lucro. En el ejercicio de la mencionada concesión estatal (epígrafe), la ONCE tiene autorizada la explotación de tres modalidades de juego de azar: modalidad «Cupón prociegos», también denominada «Cupón de la ONCE» o «Cupón», modalidad lotería instantánea y modalidad juego activo. 
En esta materia, las actuaciones de la Organización deben ajustarse a las prescripciones del ordenamiento vigente, representado por la Disposición adicional vigésima de la Ley 46/1985, de 27 de diciembre de Presupuestos Generales del Estado para 1986, modificada por la Disposición adicional cuarta de la Ley 55/1999, de 29 de diciembre, de Medidas Fiscales, Administrativas y del Orden Social, por el «Acuerdo General entre el Gobierno de la Nación y la ONCE en materia de cooperación, solidaridad y competitividad para la estabilidad de futuro de la ONCE para el período 2004-2011», aprobado por el Consejo de Ministros con fecha 27 de febrero de 2004, por los Reales Decretos 358/1991, de 15 de marzo, 1200/1999, de 9 de julio y 1359/2005, de 18 de noviembre, de Reordenación de la ONCE, así como por el Real Decreto 1336/2005, de 11 de noviembre, por el que se autoriza a la ONCE la explotación de una lotería instantánea o presorteada. Además, resultan aplicables las prescripciones vigentes de sus Estatutos [Orden TAS/2533/2006, de 27 de julio, por el que se dispone la publicación de los nuevos Estatutos de la Organización Nacional de Ciegos Españoles (BOE de 2 de agosto, núm. 183)].

Conforme al referido marco de ordenación, la ONCE debe comunicar con antelación suficiente las condiciones de todas sus modalidades de juego autorizadas al Consejo de Protectorado, como órgano al que corresponde el Protectorado del Estado sobre la Organización, para su conocimiento y verificación de que se cumplen los términos de la concesión estatal y demás normativa de general aplicación, así como para su publicación en el BOE como garantía de los consumidores ${ }^{1}$.

\section{Fuentes de financiación y modalidades de juego autorizadas.}

\subsection{Fuentes de financiación.}

La ONCE financia, principalmente, el cumplimiento de sus fines sociales y actividades a través de los recursos obtenidos en la explotación de tres modalidades de juego: la concesión estatal del cupón prociegos, la lotería instantánea y el juego activo, a las que se añadirán cuantas otras modalidades de juego sean concebidas o autorizadas por el Consejo de Ministros o, en su caso, por cualquier otra Administración competente por razón de la materia, de conformidad con la legislación vigente aplicable.

${ }^{1}$ Vide Resolución de 27 de julio de 2006, de la Secretaría de Estado de Servicios Sociales, Familias y Discapacidad, por la que se dispone la publicación de los Textos Refundidos de los Reglamentos reguladores de las distintas modalidades y productos de juego de la ONCE (BOE de 5 de agosto, núm. 186). 
Dichas modalidades de juego ajustarán su ordenación y funcionamiento a las previsiones contenidas en el Título IV de los Estatutos de la ONCE, que se subordinan a la legislación estatal aplicable en esta materia.

Tal y como disponen los Estatutos de la corporación de derecho público de carácter social, art. 5.3: «Ninguna persona o entidad pública o privada podrá vincular el resultado del sorteo del cupón o de los demás juegos autorizados a la ONCE con ningún producto o servicio, de cualquier naturaleza, que comercialice».

\subsection{Modalidades de juego autorizadas².}

La ONCE tiene autorizada la comercialización de tres modalidades de juego: modalidad cupón prociegos, también denominada cupón de la once o cupón; modalidad lotería instantánea y modalidad de juego activo.

Dentro de los límites y características definidas en los acuerdos de autorización, cada modalidad de juego contará con uno o varios productos de juego.

\subsubsection{Modalidad cupón prociegos ${ }^{3}$.}

El cupón prociegos es una modalidad de juego de carácter pasivo que tiene las siguientes características principales: a) El resultado del juego se obtiene a través de un sorteo; b) Cada sorteo cuenta con una emisión de cupones fijada y comunicada con antelación a la celebración del sorteo; c) Cada apuesta es única, pudiendo elegir el comprador alguna de las apuestas que no han sido compradas con anterioridad; d) Existe un programa de premios independiente del volumen de ventas, cuyas cuantías están determinadas con anterioridad a la celebración del sorteo.

\subsubsection{Modalidad lotería instantánea o presorteada $a^{4}$.}

La modalidad de juego denominada lotería instantánea o presorteada consiste en la posibilidad de obtención de un premio, establecido en el programa correspondiente, o definido o representado en la tarjeta, boleto o cual-

\footnotetext{
${ }^{2}$ Vide Estatutos de la Organización Nacional de Ciegos Españoles, art. 97.

${ }^{3}$ Vide Estatutos de la Organización Nacional de Ciegos Españoles, art. 98.

${ }^{4}$ Vide Estatutos de la Organización Nacional de Ciegos Españoles, art. 99.
} 
quier otro soporte electrónico o telemático empleado para su difusión y que es invisible para el jugador hasta que proceda a su revelado o apertura, a través de los medios previstos en cada producto.

La modalidad lotería instantánea cuenta actualmente con un producto con mecánica rasga y gana, al que se sumarán en el futuro cuantos otros productos sean aprobados por el Consejo General y se adecuen a lo establecido legalmente.

\subsubsection{Modalidad juego activo $^{5}$.}

La modalidad juego activo está definida por las siguientes características principales: a) El resultado del juego se obtiene a través de un sorteo; b) La emisión es variable y queda determinada por el volumen de apuestas válidas realizadas para cada sorteo; c) El comprador puede diseñar la apuesta que quiere realizar, elegir una apuesta automática o elegir un boleto preimpreso; d) Pueden existir dos o más apuestas iguales; e) Alguno de los premios tiene un carácter variable, basado en el volumen de ventas y en el número de apuestas agraciadas.

La modalidad juego activo cuenta actualmente con un producto denominado «El Combo», al que se sumarán en el futuro cuantos otros productos sean aprobados por el Consejo General y se adecuen a lo establecido legalmente.

\subsubsection{Otras que puedan autorizarse en el futuro.}

En el futuro la ONCE podrá comercializar cualquier otra modalidad de juego que le sea autorizada por el Gobierno de la Nación, o por cualquier otra Administración competente por razón de la materia.

\section{EL CUPÓN O BOLETO.}

\section{Concepto.}

La primera vez que se empleó el nombre de cupón relacionado con loterías benéficas para ciegos fue en 1933, cuando en Madrid surgió el cupón del chiquilín: rifa combinada con cromos coleccionables en un álbum. Posterior-

\footnotetext{
${ }^{5}$ Vide Estatutos de la Organización Nacional de Ciegos Españoles, art. 100.
} 
mente, la Sociedad de Ciegos "La Hispalense" de Sevilla, llamó a su lotería Cupón Pro-ciegos, nombre que luego pasó a tener el de la $\mathrm{ONCE}^{6}$.

El 8 de mayo de 1939 se considera como el día en el que la ONCE celebró los primeros sorteos del cupón pro-ciegos, pese a que muchas asociaciones que vendían rifas con anterioridad, tras su incorporación a la nueva organización, continuaron haciéndolo hasta que terminaron sus existencias ${ }^{7}$. También debo señalar que en muchas partes de Levante, entre Valencia y Almería, existe la tradición de dar a cada cifra de las dos últimas del cupón un nombre diferente; así habitualmente, compradores y vendedores los denominaban por estos motes y no por el número correspondiente. No se sabe cuando comenzó esta costumbre, pero, en todo caso, es anterior a la creación de la ONCE, pues ya era utilizado en diferentes rifas surgidas en las zonas levantinas ${ }^{8}$.

${ }^{6}$ Vide ONCE, Historia del cupón, ONCE, Madrid, 1987, sin paginar.

${ }^{7}$ Ibídem. Respecto al precio del cupón señala: «Como indicamos anteriormente, el Cupón Pro-Ciegos, entre 1939 y 1983, no varió su estructura, diseño, etc. Durante estos años tan sólo sufrió variaciones el precio:

- El Cupón se comenzó a vender a 10 céntimos.

- El 1 de septiembre de 1950 se elevó el precio a 20 céntimos.

- 5 años después, el 21 de septiembre de 1955, se establecía éste en 50 céntimos.

- 1 peseta el 2 de enero de 1958.

- Justamente 6 años más tarde, en 1964, el Cupón comenzó a costar el doble, 2 pesetas.

- 5 pesetas a partir del 1 de octubre de 1969.

- En el año 76, el 2 de enero, el Cupón comenzó a venderse a 10 pesetas.

- 25 pesetas desde el 1 de mayo de 1979».

Vide ONCE, 65 años de historia, ONCE, Madrid, 2004, p. 73, donde detalla la evolución del premio del cupón y del premio de las dos últimas cifras (las cantidades que aparecen guardan también este orden): «Del 8 de mayo de 1939 al 31 de agosto de 1950: 25 pts; 2,50 pts. Del 1 de septiembre de 1950 al 20 de septiembre de 1955: 50 pts; 5 pts. Del 21 de septiembre de 1955 al 31 de diciembre de 1957: 125 pts; 12,50 pts. Del 2 de enero de 1958 al 31 de diciembre de 1963: 250 pts; 25 pts. Del 2 de enero de 1964 al 30 de septiembre de 1969: 500 pts; 50 pts. Del 1 de octubre de 1969 hasta el 31 de diciembre de 1975: 1.250 pts; 125 pts. Del 2 de enero de 1976 al 30 de abril de 1979: 2.500 pts; 250 pts. Del 2 de mayo de 1979 al 31 de diciembre de 1983: 6.250 pts; 625 pts».

${ }^{8}$ Vide Once, Historia del cupón, ONCE, Madrid, 1987, sin paginar. En este trabajo se relaciona el nombre que el pueblo alicantino dio a los números: «1: El Galán; 2: El Sol; 3: El Niño; 4: La Cama; 5: La Punta; 6: El Corazón; 7: La Luna; 8: La Dama; 9: El Arpa; 10: La Rosa; 11: El Clavel; 12: La Talega; 13: El Verde; 14: Las Cerezas; 15: La Uva; 16: La Guitarra; 17: El Navío; 18: El Ramo; 19: San José; 20: España; 21: Francia; 22: La Manzana; 23: El Melón; 24: La Galera; 25: El Cañón; 26: El pollo; 27: La Pajarita; 28: Alicante; 29: Aragón; 30: El León; 31: El Caballo; 32: La Bomba; 33: La Torre; 34: El Pato; 35: El Infierno; 36: La Ensalada; 37: La Espada y Daga; 38: El Perro; 39 : El Toro; 40: La Campana; 41: El Negro; 42: La Estrella; 43: La Corona; 44: El Clarín; 45: El Tambor; 46: El Sombrero; 47: El Mundo; 48: La Negra; 49: La Breva; 50: El Cartucho; 51: La Cabra; 52: El Tomate; 53: El Pimiento; 54: La Mala Noche; 55: Los Gallegos; 56: La Lechuga; 57: La Za- 
Tal y como establecía el Reglamento de la Organización Nacional de Ciegos (Orden del Ministerio de Gobernación de 28 de octubre de 1939), art. 14, se ponía a la venta el denominado "cupón pro-ciegos", con carácter voluntario, como forma exclusiva de ingresos para los afiliados a la misma.

El cupón o boleto es el documento contractual legalmente emitido en el que se establecen recíprocamente las obligaciones de las partes, que consisten fundamentalmente en que el cliente comprador paga un precio cierto por el cupón o boleto unidad y la ONCE se compromete a dar a cambio una cantidad de dinero, conforme a la escala de premios preestablecida, en función de un hecho incierto o aleatorio, consistente en la coincidencia total o parcial y en el orden determinado de los números contenidos en el cupón o boleto, hecho aleatorio que se despeja mediante el instrumento o la fórmula del sorteo celebrado con periodicidad diaria, mensual, anual, etc. ${ }^{9-10}$ o el revelado, y que supone el me-

nahoria; 58: Los Limones; 59: El Canario; 60: La Abuela; 61: La Pipa; 62: El Piojoso; 63: La Paella; 64: La Casa; 65: La Pelea; 66: Las Monjas; 67: El Fraile; 68: El Rosario; 69: La Mudanza; 70: El Albaricoque; 71: El Maestro; 72: El Higo; 73: El Conejo; 74: La Escalera; 75: El Gato; 76: El Agua; 77: Las Banderas; 78: El Escarabajo; 79: El Marrano; 80: La Lavandera; 81: El Matrimonio; 82: El Orinal; 83: La Dama y el Niño; 84: Casamiento; 85: La Palmera; 86: Mierda; 87: El Pescado; 88: Las Mamas; 89: La Gamba; 90: El Abuelo; 91: El Borracho; 92: El Palomo; 93: La Revolución; 94: La Rata; 95: El Pavo; 96: La Explanada (Paseo principal de Alicante, por lo cual en otras ciudades el 96 es el Parque, La Alameda, etc.); 97: La Gallina; 98: El Borrego; 99: La Agonía; 00: La Muerte».

${ }^{9}$ Vide Jesús MONTORO MARTÍNEZ, Los ciegos en la historia, Tomo V, ONCE, Madrid, 1998, p. 113. Debo señalar, que desde el 2 de enero de 1984, se estableció en la ONCE un único sorteo para todo el país. También debo destacar que desde el día 5 de octubre de 1985, no se vende cupón de la ONCE en sábado.

${ }^{10}$ Vide Antón ALVAREZ RUIZ, La función social de la publicidad de la ONCE, Escuela Libre Editorial, Madrid, 2003, pp. 73-74, donde explica el brand wheel (rueda de marca) del cupón. Básicamente consiste en una metodología que se aplica a los productos de gran consumo, porque permite conocer con detalle las imágenes y los elementos afectivos que los consumidores asocian a los productos y a las marcas. De esta forma, se utiliza para poder detectar diferencias, a veces muy sutiles, entre marcas y productos técnicamente muy parecidos sobre las que sustentar un posicionamiento competitivo en el mercado. Lo habitual es no aplicar la brand wheel a servicios o marcas del sector terciario (cupón), que no se desenvuelven en mercados tan despersonalizados y competitivos.

La "Brand Wheel" del cupón de la ONCE es la siguiente:

\begin{tabular}{|l|l|l|}
\hline & PRIMARIOS & SECUNDARIOS \\
\hline \multirow{2}{*}{ ATRIBUTOS } & Barata & Gran presencia en medios \\
& Fácil de conseguir & Poco tiempo entre apuestas y sorteo \\
& Frecuente cotidiana & \\
& Popular & \\
& Conocida & \\
& Sencilla & \\
\hline
\end{tabular}


dio excepcional de ingresos autorizado y concedido por el Gobierno en monopolio, de la Corporación de Derecho Público ONCE ${ }^{11}$.

Se entiende por cupón o boleto emitido por terminal de punto de venta, aquel que se imprime por un agente vendedor en el momento de efectuarse la transacción, utilizando un terminal de punto de venta.

La finalidad esencial de esta modalidad de juego de azar es doble: procurar empleo y atender las necesidades de los afiliados a la Corporación de Derecho Público creada a tal efecto. Y a pesar de que se preveía su carácter residual, hoy es su recurso fundamental, tal y como ha determinado la STC 171/1998 (Pleno), de 23 de julio (F.J.):

$« 5$. Tanto en la norma fundacional como en las que posteriormente han procedido a reordenar la estructura organizativa de la ONCE se ha atendido y se atiende de forma expresa a los recursos económicos de los que dispone la entidad en orden al cumplimiento de los fines de interés público que se le encomiendan. Entre ellos, ya en el Reglamento de 1939 se contemplaba el producto de la implantación y organización por la Sec-

\begin{tabular}{|l|l|l|}
\hline BENEFICIOS & $\begin{array}{l}\text { Cómoda/Fácil de jugar } \\
\text { Me entero enseguida del premio }\end{array}$ & $\begin{array}{l}\text { Me entero fácilmente del premio } \\
\text { Da para un capricho }\end{array}$ \\
\hline VALORES & Ilusión diaria & $\begin{array}{l}\text { Me siento bien jugando } \\
\text { Contribuyo a una labor social }\end{array}$ \\
\hline PERSONALIDAD & $\begin{array}{l}\text { Fiable/de confianza } \\
\text { Sociable } \\
\text { Amable } \\
\text { Amistoso } \\
\text { Modesto } \\
\text { Entrañable }\end{array}$ & $\begin{array}{l}\text { Optimista } \\
\text { Dinámico } \\
\text { Moderno } \\
\text { Con humor } \\
\text { Atractivo } \\
\text { Pacífico }\end{array}$ \\
\hline
\end{tabular}

Los datos fueron obtenidos de una conferencia impartida por la Dirección de Relaciones Públicas y Publicidad de la ONCE, ofrecida en Madrid, en 1993.

11 Vide: Rafael de LORENZO GARCÍA, "La Organización Nacional de Ciegos Españoles: breve estudio de una Organización singular", en AAVV, El sector no lucrativo en España, Escuela Libre Editorial, Madrid, 1993, pp. 270-274: «El cupón de la ONCE»; ASV, "Cupón de la ONCE falsificado", Diario El País (versión electrónica), 24-2-1988; EFE, "Detenido un español en la frontera portuguesa con 500.000 cupones falsos de la ONCE", Diario El País (versión electrónica), 24-9-1989. 
ción de Trabajo del denominado "cupón pro-ciegos», calificado como forma «excepcional y exclusiva» de ingresos para los no videntes y, por consiguiente, como fuente de recursos de la ONCE, al que además se confería un carácter residual, en cuanto actividad, ya que la venta del mencionado «cupón pro-ciegos» se preveía que fuera ejercitada por los no videntes «imposibilitados de desempeñar una profesión u oficio especial». Significativo de dicho aspecto resulta el que su implantación y organización se le encomendara, de entre las secciones en las que se estructuraba la ONCE, a la Sección de Trabajo, a quien correspondía la organización y el fomento del trabajo de los invidentes (art. 14 de la Orden del Ministerio de Gobernación de 28 de octubre de 1939). En idénticos términos, como recursos económicos de la entidad vinculados al cumplimiento de los fines que se le atribuyen, aparecen caracterizados en la posterior normativa por la que se procede a reordenar la estructura organizativa de la ONCE los beneficios derivados de la explotación en exclusiva de la venta del "cupón pro-ciegos» [arts. 3 del Real Decreto 1041/1981, de 22 de mayo; 3, b) del Real Decreto 358/1991, de 15 de marzo y 5 de los Estatutos].

Así pues, el denominado «cupón pro-ciegos» aparece estrechamente vinculado, tanto históricamente como en la actualidad, a la decisión estatal de creación de la ONCE y al cumplimiento de los fines de indudable interés público que tiene encomendados, en razón de los cuales se define hoy aquélla como una Corporación de Derecho Público de carácter social, configurándose los rendimientos de aquél como un recurso financiero de una determinada entidad en orden a la satisfacción de los intereses públicos que ha de atender con su actividad respecto a un concreto colectivo de personas, los incapacitados visuales, con notables dificultades de integración, para los cuales la ONCE ha de perseguir la consecución de su autonomía personal y plena integración en la sociedad (art. 2.1 del Real Decreto 358/1991). En otras palabras, la justificación de la concesión que históricamente se ha mantenido, de la explotación del "cupón pro-ciegos», como fuente de recursos financieros de la entidad, no reside sino en la necesidad de dotarle de los medios económicos suficientes para el cumplimiento de los relevantes fines de indudable interés público que ha asumido desde su creación y asume en la actualidad. Medios económicos que arbitró el Estado mediante la autorización de ese sorteo en lugar de asignar una consignación con cargo a su propio presupuesto, constituyendo así una fuente de ingresos de la ON$\mathrm{CE}$ que ha sido y sigue siendo el principal recurso financiero de la entidad, soporte, por lo tanto, imprescindible e indispensable para el desempeño de las actividades que realiza tendentes a la satisfacción de los fines de interés público que tiene encomendados y que son su razón de ser y que hace posible el sostenimiento de aquellas actividades y la pervivencia de la propia enti- 
dad. Conservando además el mismo carácter de actividad de los invidentes que presentaba en el momento de la constitución de la ONCE, constituyendo un medio singular de trabajo reservado a aquéllos o a otras personas afectadas con minusvalías diferentes -más de 21.000 personas- para posibilitar su integración profesional y social.

El sorteo del cupón, también conocido tradicionalmente como «lotería de los ciegos», ha sido y sigue siendo, pues, el medio económico indispensable y esencial para el logro por la Corporación de los referidos fines. $[\ldots] »$.

\section{Naturaleza jurídica.}

Los cupones o boletos de la ONCE deben catalogarse como títulos al portador $^{12}$, cuyo rendimiento tiene naturaleza de ingreso público y supone el medio económico suficiente para el cumplimiento de los relevantes fines de interés público que ha asumido desde su creación y asume en la actualidad. Así lo ha establecido la STC 171/1998 (Pleno), de 23 de julio, Ar. 171, en el Fundamento Jurídico 2:

12 Vide Sentencia del Tribunal Superior de Justicia de Asturias núm. 532/1999 (Sala de lo Contencioso-Administrativo, Sección $1^{a}$ ), de 29 de junio, Ar. 1868:

«FUNDAMENTOS DE DERECHO

PRIMERO. Se impugna por la recurrente la denegación presunta del recurso interpuesto contra la Resolución de la ONCE de 12 de abril de 1996 por la que se le denegaba el pago de 2.500.000 pesetas correspondientes al premio de un cupón del sorteo del día 30 de enero de dicha anualidad, fundándose dicha impugnación en la manifestación de haber extraviado el cupón identificado con la serie 34 del número 61.452 que había adquirido en el «Bar Baizán» de Gijón junto con otros amigos de una peña que diariamente acude a dicho establecimiento, tal y como éstos pueden acreditar; señalando asimismo que sólo después de iniciado el presente procedimiento pudo percatarse de que el citado cupón había sido abonado en esta Delegación Territorial. Indicándose como fundamentación jurídica el Real Decreto 358/1991 de 15 marzo de 1991 y concordantes.

SEGUNDO. La señora Letrada de la ONCE se opone a la demanda en base a las alegaciones siguientes: $\left.1^{\circ}\right)$ Los cupones de la ONCE se consideran títulos al portador y constituyen el único documento válido para acreditar el premio sin que pueda sustituirse por ningún otro medio; $2^{\circ}$ ) El plazo hábil para cobrar el cupón es de 30 días naturales, habiéndose presentado al cobro tres días antes de la fecha límite en la Agencia de Pola de Siero y de ahí que en un primer momento se indicara al esposo de la recurrente que aún no había sido abonado; $3^{\circ}$ ) Resulta irrelevante que en los cupones figure el número del DNI de los perceptores del premio o que se cobren en un lugar u otro (artículo 13, circular 7/1991); $4^{\circ}$ ) No existe enriquecimiento injusto para la recurrida al haber abonado el importe a quien lo presentó y entregó.

TERCERO. Los cupones de la ONCE deben catalogarse como títulos al portador dada su similitud con los billetes de la Lotería Nacional por lo que, en principio, resulta inexcusable su presentación para el cobro del premio, tal y como, por otra parte, establece el artículo 13 de la circular 7/1991, y si 
«[...]. Asimismo, en defensa de la constitucionalidad de los preceptos impugnados aduce también la competencia del Estado sobre las bases del régimen jurídico de las Administraciones Públicas (art. 149.1.18 CE) y sobre las fundaciones y asociaciones de carácter benéfico-asistencial y ámbito nacional (art. 9.24 EAC), dado que la ONCE es una entidad de Derecho Público que desarrolla su actividad en todo el territorio del Estado, sometida a la tutela y al protectorado de éste y que explota aquel juego como medio de financiar las actividades que definen y justifican su existencia. En definitiva, tanto el hecho de que los rendimientos de la "Lotería Pro-Ciegos» son ingresos públicos del Estado, como el relativo a la relación de instrumentalidad que dicha lotería tiene respecto a todo el complejo de actividades de la ONCE son factores que, a su juicio, determinan la titularidad competencial del Estado respecto a la citada organización y a la gestión del «cupón pro-ciegos».

$\mathrm{Al}$ igual que sucede con la lotería, este contrato manifiesta las características propias de un contrato de adhesión, pues el comprador no tiene más alternativa que pasar por todas y cada una de las condiciones o requisitos que se han establecido. Tales imposiciones se justifican por la propia dinámica del juego, por las cautelas y las condiciones inherentes a la seguridad jurídica propias de una actividad de esta naturaleza. Por todo ello, nunca se coloca al cliente en situación de indefensión, sino todo lo contrario, pues resulta esencial garantizar sus derechos con total transparencia.

bien es cierto que el Tribunal Supremo tiene en ocasiones declarado que dicho requisito de la presentación puede sustituirse por otros relevantes medios de prueba que acrediten tanto la legitimidad posesoria del reclamante como la coincidencia absoluta entre el número y fracción del billete premiado (Sentencia del Tribunal Supremo de 3 de marzo de 1989, por todas), ello será siempre sobre la base de que dicho título no haya sido abonado (Sentencia del Tribunal Supremo de 11 de noviembre de 1994), tal y como aquí ha sucedido según se desprende del testimonio del cupón obrante en el recurso en que aparece abonado en Siero en fecha 26 de febrero de 1996, circunstancia ésta que, en su caso, podría dar lugar a que por la recurrente se ejercitaran las acciones correspondientes en la vía oportuna (incluso la penal) mas en forma alguna motivar la anulación de la resolución recaída en vía administrativa que, por las razones apuntadas, ha de estimarse conforme a derecho, sin que se estime, por otra parte, necesaria la práctica para mejor proveer de la testifical propuesta por la recurrente dado que el resultado de la misma nada podría influir en el resultado del recurso, teniendo en cuenta los motivos en base a los que éste se desestima». 


\section{Clasificación.}

\subsection{Reformas del cupón y otras modalidades de juego que han determinado su modificación.}

\subsubsection{La década de los 80 y los 90 .}

Exponer una clasificación respecto al cupón y las otras modalidades de juego explotadas por la ONCE, implica hacer una breve referencia a las reformas que inicialmente afectaron al cupón, y después se extenderían a otras modalidades de juego. Se trata de un periodo de la historia de la ONCE que ha condicionado el devenir económico de la misma.

Desde su nacimiento mantiene una estructura general muy parecida en lo relativo a distribución de premios: se emitían series de mil números, siendo el premio mayor de 250 veces lo jugado. Su precio varió desde los diez céntimos iniciales a las 25 pesetas (desde el 1 de mayo de 1979). El porcentaje a distribuir en premios era del $47,5 \%$ y los sorteos se celebraban diariamente en cada Delegación Provincial y Comarcal.

La primera gran reforma se establece por la Circular no 705, de 26 de mayo de 1983, y tendrá efectos a partir del 1 de enero del año siguiente:

«El Consejo General de la ONCE en sesión ordinaria celebrada el 26 de mayo de 1983, adoptó el acuerdo de poner en práctica la reforma del cupón, la cual es del tenor siguiente:

$1^{\circ}$. Encargar a la Dirección General que prepare todo lo necesario para poner en práctica una reforma en la estructura del cupón a partir del 1 de enero de 1984, con las siguientes características:

a) Estructuración del cupón en series de 10.000 números, del 0 al 9.999.

b) El precio del cupón será de 50 pesetas por unidad.

c) El tamaño del cupón será, aproximadamente, el del doble del que se utiliza actualmente en los sorteos diarios, de acuerdo con las características que permite la imprenta del cupón y que se desarrollan en el informe del Delegado General, que aporta como número 1.

d) El reparto de premios seguirá siendo del 47,5 por ciento, de acuerdo con la relación que se acompaña, como documento número 2.

e) La distribución del cupón a las diferentes Delegaciones Territoria- 
les se hará, respetando, en lo posible, las necesidades de numeración y de cantidad de cupones iguales.

f) El sorteo tendrá carácter nacional.

2ํ․ La Delegación General realizará con carácter urgente, las gestiones necesarias tendentes a asegurar la disponibilidad de un sistema de comunicación ágil para la transmisión del número premiado a partir del mismo momento en que se implante la reforma.

$3^{\circ}$. En cuanto al pago de premios que comporta este sorteo, se encarga a la Delegación General la preparación de la infraestructura bancaria necesaria con el fin de descongestionar lo más posible este servicio en esta Delegación.

$4^{\circ}$. Dar a este Acuerdo el carácter de ejecutivo y urgente.

Para el cumplimiento y ejecución de dicho Acuerdo, esta Delegación General ha realizado las gestiones pertinentes y promulgado la normativa a la que debe ajustarse el procedimiento a seguir. Todo lo cual obra en poder de todas y cada una de las Delegaciones de este Organismo, si bien se transcribe el precitado Acuerdo, a efectos de público conocimiento, reseñando por correo aparte se remite la normativa reguladora de dicho sorteo nacional, en la que se recoge la distribución o reparto de premios, así como las demás cuestiones inherentes al mismo» ${ }^{13}$.

Esta primera reforma supuso la celebración de un único sorteo para todo el territorio nacional, de lunes a sábado, y el aumento del número de cupones a la venta.

La segunda reforma, tuvo lugar el 4 de octubre de 1985, con ocasión de la negociación del segundo convenio colectivo, lo que motivó el descanso la-

13 Vide Jesús MONTORO MARTÍNEZ, Los ciegos en la historia, Tomo V, o.c., p. 124, donde señala: «Los sorteos extraordinarios del 13 de diciembre de 1981 y del 1 de enero de los años 1983 y 1984, más la reforma del cupón implantada al día siguiente de este último, hechos consumados por la ONCE sin consultarlos con el Gobierno y, por consiguiente, sin su autorización, enfadaron muchísimo al Ministro de Economía y Hacienda, quien amonestó severamente a Don Antonio Vicente Mosquete, Presidente del Consejo General de la Entidad, recordándole que el Organismo Tiflológico no podía realizar reforma alguna en la estructura y venta del cupón sin previa autorización del Gobierno, pero el señor Mosquete no cedió a las presiones, porque comprobaba con gran satisfacción que en 1984 se facturaban con el cupón 104.000 millones de pesetas, frente a los 45.000 facturados en 1983». 
boral en sábado. Para compensar se implantó los viernes un sorteo de carácter especial, el "supersorteo fin de semana".

La tercera reforma del cupón, tiene lugar a finales de 1987, y su mayor exponente fue "El Cuponazo". Implicaba que las series fuesen de 100.000 números, el precio unitario era de 100 pesetas, y se produce un importante incremento en los primeros premios, pasando la asignación de éstos del 47,5\% al $52 \%$.

La siguiente reforma tuvo lugar en mayo de 1991, que trató de implantar el abono semanal ${ }^{14}$. A partir del 2 de mayo de 1996, se eleva el precio del cupón de 100 a 150 pesetas de lunes a jueves y se establece un premio de 3.800.000 pesetas y 100.000 pesetas para el número anterior y posterior al agraciado con el premio principal. Como medida de impacto (en la fecha reseñada: 2 de mayo de 1996) la ONCE decide incorporar el premio de "El sueldazo" para 10 series consecutivas de anterior y 10 del posterior, al premio mayor consistente en 250.000 pesetas y 24 mensualidades de 100.000 pesetas. Durante ocho meses cada primer viernes se dota al cupón con un premio de 200 millones de pesetas.

Progresivamente se incrementa la cantidad de emisión del cupón, el precio y se llega a un porcentaje destinado a premios en un máximo del 55 por ciento de la emisión de cada sorteo y se autoriza la posibilidad, además, de realizar hasta seis sorteos de carácter extraordinario. En diciembre de 1999 se lanza el "Supercupón Fin de Semana", con premios que impactan en el público al sobrepasar (suma global de todos los tipos de premios) los 750 millones de pesetas cada domingo ${ }^{15}$.

\subsubsection{La reforma de comienzos del siglo XXI.}

El 15 de agosto de 2000 se celebra el primer sorteo extraordinario de esta etapa. El 5 de enero de 2001 aplicó nuevos cambios al cupón. La primera reforma del siglo XXI va a venir señalada en el cupón de los viernes, que sin modificar su precio de 250 pesetas, dobló la cuantía del cuponazo a las cinco cifras y series de 250 a 500 millones ${ }^{16}$.

\footnotetext{
14 Vide AAVV, El sector no lucrativo en España, Escuela Libre Editorial, Madrid, 1993, pp. 273-274.

15 Vide ONCE, 65 años de historia, ONCE, Madrid, 2004, pp. 120-23.

${ }^{16}$ Ibídem, p. 137.
} 
La Resolución de la Secretaría General de Asuntos Sociales de 30 de enero de 2004 (BOE de 24 de febrero, núm. 47), da publicidad al reglamento regulador del sorteo del cupón de la ONCE, reglamentación aprobada por el Consejo General de la Organización, que podrá ser objeto de desarrollo en todos sus actos con plenas garantías de seguridad, transparencia y publicidad. Dicho reglamento ha sido modificado parcialmente a través de la Resolución de la Secretaría de Estado de Servicios Sociales, Familias y Discapacidad, de 15 de abril de 2005 (BOE de 10 de mayo, núm. 111).

El Acuerdo del Consejo de Ministros de 27 de febrero de $2004^{17}$, por el que se aprueba el "Acuerdo General entre el Gobierno de la Nación y la Organización Nacional de Ciegos Españoles (O.N.C.E.) en materia de cooperación, solidaridad y competitividad para la estabilidad de futuro de la ONCE, para el período 2004-2011" determina entre otras materias las condiciones generales del régimen de los sorteos del cupón y de otras modalidades de juego explotadas por la ONCE, ordenando a su vez, su publicación en el "Boletín Oficial del Estado", como garantía de los consumidores.

La cláusula 19.1 de dicho Acuerdo establece que el Consejo de Protectorado aprobará un nuevo documento sobre "procedimientos y criterios de control sobre las materias concernientes al cupón prociegos y otras modalidades de juego autorizadas a la ONCE" que sustituya al aprobado en sesión de 29 de febrero de 2000, con el fin de adaptarlo a las novedades introducidas en el nuevo Acuerdo General.

La Disposición Transitoria del Acuerdo de 27 de febrero de 2004 establece que, en tanto no se apruebe el nuevo documento, siguen vigentes los procedimientos y criterios de control sobre las materias relativas al cupón y otras modalidades de juego autorizadas a la ONCE aprobadas en sesión de 29 de febrero de 2000 .

En cumplimiento de los dispuesto en el Acuerdo del Consejo de Ministros de 27 de febrero de 2004, así como en los procedimientos y criterios de

17 Vide Resolución de 15 de octubre de 2004, de la Secretaría de Estado de Servicios Sociales, Familias y Discapacidad, por la que se da publicidad al programa de sorteos de los juegos del cupón y de "El Combo" autorizado a la ONCE, para el cuarto trimestre del año 2004 (BOE de 22 de octubre, núm. 255). Vide Resolución de 15 de julio de 2005, de la Secretaría de Estado de Servicios Sociales, Familias y Discapacidad, que da publicidad a la modificación de determinados aspectos del Reglamento regulador de "El Combo" de la ONCE (BOE de 10 de agosto, núm. 190). 
control sobre las materias relativas al cupón, la Comisión Permanente del Consejo de Protectorado en reunión de 15 de octubre de 2004 ha verificado que la propuesta de la ONCE se ajusta a los términos del citado Acuerdo.

Especial incidencia ha tenido la aprobación del Real Decreto 1359/2005, de 18 de noviembre, por el que se modifica el Real Decreto 358/1991, de 15 de marzo, por el que se reordena la ONCE, al añadir un nuevo apartado 4 en el artículo 7, con la siguiente redacción: «La ONCE explotará una modalidad de lotería, de ámbito nacional, denominada lotería instantánea o presorteada, en los términos, condiciones, alcance y plazos previstos en el Real Decreto 1336/2005, de 11 de noviembre, por el que se autoriza a la Organización Nacional de Ciegos Españoles la explotación de una lotería instantánea o presorteada». Asimismo ha resultado capital la publicación de la Orden TAS/2533/2006, de 27 de julio, por la que se dispone la publicación de los nuevos Estatutos de la Organización Nacional de Ciegos Españoles (BOE de 2 de agosto, núm. 183) y la Resolución de 27 de julio de 2006, de la Secretaría de Estado de Servicios Sociales, Familias y Discapacidad, por la que se dispone la publicación de los Textos Refundidos de los Reglamentos reguladores de las distintas modalidades y productos de juego de la ONCE (BOE de 5 de agosto, núm. 186).

Lo cierto es que la ONCE mantiene una actitud tremendamente innovadora que se ha materializado a lo largo de toda su trayectoria ${ }^{18}$. Su consecuencia más inmediata ha sido la elaboración de alternativas que permitan un mayor grado de inserción en esta actividad.

18 Vide diario El País de 13 de diciembre de 2002, "La ONCE subirá el cupón un 50\% y hará dos nuevos sorteos al mes": «La ONCE anunció ayer que, a partir del 2 de enero, el cupón diario costará 1,5 euros, lo que supone un aumento del precio del $50 \%$. La subida irá acompañada de dos nuevos sorteos (viernes especial del mes y domingo especial del mes, a 2,5 euros) y de mayores premios. De lunes a viernes, el premio a las cinco cifras y serie pasa de 100.000 a 300.000 euros. [...]. Con los nuevos sorteos mensuales y la nueva estructura de premios [...], la ONCE trata de mantener el tipo en un sistema de juego como el cupón, de tipo pasivo, que muestra una tendencia descendente en ventas, según admitió ayer el director general de la ONCE, Miguel Carballeda.

De hecho, pese al aumento en el precio del cupón diario en 2003, la organización que preside José María Arroyo, sólo prevé en 2003 "igualar" las ventas registradas en 2001, hasta situarlas en 2.475,89 millones de euros. En 2002 (ejercicio aún por cerrar), según Carballeda, la ONCE logró mantener el número de clientes, pero los ingresos por venta del cupón cayeron un 3\%. La ONCE proyecta lanzar nuevos juegos en un futuro. Según Carballeda, la organización estaría en disposición de lanzar un nuevo producto, "más activo", en enero de 2004, aunque no es una decisión tomada. 


\subsection{Lotería instantánea o presorteada y lotería condicionada a la realización del sorteo.}

La lotería instantánea o presorteada consiste en la posibilidad de obtención de un premio establecido en el programa correspondiente, o definido o representado en la tarjeta, boleto o cualquier otro soporte electrónico o telemático empleado para su difusión y que es invisible para el jugador hasta que proceda a su revelado o apertura, a través de los medios previstos en cada producto ${ }^{19}$.

Mientras que la fórmula tradicional implica esperar hasta la realización del sorteo previamente anunciado para saber si el boleto en nuestro poder ha sido premiado.

Lo que sí seguirá creciendo el próximo año es el beneficio bruto del grupo (ONCE y Corporación empresarial), que se situará en 52 millones de euros frente a los 46 millones previstos en el presente ejercicio y los 30 millones obtenidos en 2001. [...].

Para el próximo año, la ONCE, bajo supervisión de la Administración, que forma parte del Consejo de Protectorado de la organización, ha elaborado un presupuesto equilibrado de 2.675 millones de euros, con la principal partida de gastos (1.202,87 millones de euros) dedicada al pago de premios. A gastos de personal (la ONCE tiene 63.296 afiliados y 59.147 empleados, de los cuales un $60 \%$ son discapacitados) la ONCE dedicará el próximo ejercicio 1.018 millones de euros.

Los directivos de la organización de ciegos destacaron en conferencia de prensa que los compromisos asumidos en el año 1999 para crear hasta el ejercicio 2008, 20.000 empleos, se han cumplido en un $93 \%$, ya que hasta la fecha, se han creado 18.548 nuevos empleos netos en la ONCE. La educación y el deporte serán, también objetivos prioritarios en 2003».

${ }^{19}$ Vide Real Decreto 1336/2005, de 11 de noviembre, por el que se autoriza a la Organización Nacional de Ciegos Españoles la explotación de la lotería instantánea o presorteada (BOE de 22 de noviembre, núm. 279): «La Organización Nacional de Ciegos Españoles (ONCE), corporación de derecho público de carácter social, ha desempeñado a lo largo de sus más de 60 años de historia una labor trascendental en la integración y autonomía personal de los ciegos españoles, que con el transcurso de los años se ha ido extendiendo paulatinamente, sobre la base del principio de la solidaridad, a otras personas discapacitadas, por medio de la Fundación ONCE, todo ello dentro de un marco de colaboración con la Administración General del Estado.

Para la consecución de estos fines, la ONCE ha contado tradicionalmente con los ingresos que le ha reportado la comercialización del cupón "prociegos", ingresos que se han dedicado a atender los compromisos sociales de la organización para conseguir el bienestar la integración social de sus afiliados y cumplir el citado compromiso de solidaridad adquirido con otros discapacitados, y que se ha destinado a crear, mantener y mejorar la calidad de los puestos de trabajo y para impulsar la formación de estas personas.

La actual evolución de los juegos en España hace preciso dotar a la ONCE de nuevos instrumentos para que esta organización pueda continuar disponiendo de los medios necesarios para el cumplimiento de sus objetivos y fines sociales.

A fin de atender los mencionados compromisos, se entiende necesario que la ONCE comercialice una nueva modalidad de lotería, de ámbito nacional, que satisfaga las preferencias de aquellos jugadores que demandan una lotería de "premio inmediato" o "instantáneo". 


\subsection{Tipos de soporte de comercialización: preimpresos, emitidos por termi-} nales de punto de venta, emitidos por cualquier otro soporte electrónico o telemático, emitidos en cualquier otro soporte o procedimiento que se ajuste a la normativa aplicable en vigor, o que se autorice en el futuro ${ }^{20}$.

La comercialización de los productos de juego de la ONCE podrá utilizar: a) Cupones, boletos o apuestas preimpresos; b) Cupones, boletos o apuestas emitidos por terminales de punto de venta; c) Cupones, boletos o apuestas emitidos mediante cualquier otro soporte electrónico o telemático que esté contemplado en el reglamento regulador de la modalidad o producto de juego, de acuerdo con las autorizaciones vigentes en cada momento; d) Cualquier otro soporte o procedimiento que se ajuste a la normativa aplicable en vigor, o que se autorice en el futuro.

\subsection{Formas de comercialización: para un único sorteo o para varios sorteos.}

La comercialización se podrá realizar utilizando dos tipos de producto: cupón o boleto que representa participación en un único sorteo y cupón o boleto representativo de participaciones en varios sorteos.

\subsection{Modalidades de comercialización: productos de juego.}

\subsubsection{El cupón de la ONCE ${ }^{21}$.}

En suma, las razones expuestas de preservar tanto la labor social llevada a cabo por la ONCE como la estabilidad en el empleo de las personas que comercializan los juegos que tiene concedidos, unidas a las circunstancias de carácter comercial señaladas, justifican la autorización de la gestión de una lotería "instantánea" o "presorteada" por la ONCE, en todo el territorio nacional y por medio de los vendedores integrados en su plantilla de trabajadores».

${ }^{20}$ Vide Estatutos de la Organización Nacional de Ciegos Españoles, art. 105.

21 Vide Memoria de la Dirección General de la ONCE, año 2003, importancia relativa de los productos ONCE:

\begin{tabular}{|l|r|}
\hline Cupón de lunes a viernes & $49 \%$ \\
\hline Cuponazo de viernes & $38 \%$ \\
\hline Supercupón fin de semana & $10 \%$ \\
\hline Extraordinario & $3 \%$ \\
\hline
\end{tabular}

Vide ONCE, “¿A qué les gusta jugar?, Punto de Venta, 40, (2004), p. 14: «El cupón diario tiene una alta tasa de clientes que juegan una o menos veces por semana y cada vez que lo hacen compran un solo cupón. El número de personas que asegura comprar el cupón diario es de aproximadamente nueve millones y medio pero, alrededor de seis millones de jugadores compran con 


\section{A. Sorteo del cupón de lunes a jueves ${ }^{22}$.}

Se determina por parte del Consejo de Protectorado la cantidad máxima de emisión por sorteo, la cantidad destinada a premios, la distribución de premios por emisión y el precio del cupón.

esta frecuencia baja. Los jugadores que compran un día a la semana y cuando lo hacen sólo juegan un cupón diario, es de cinco millones ochocientos mil.

La mitad de los jugadores del cuponazo de viernes, que ascienden a 8.200.000 personas, compran todos o casi todos los viernes del mes, y algo más de 4.000.000 de jugadores lo hacen con una intensidad alta. Se acercan a los puntos de venta (sea para adquirir la cantidad que sea) todos los sorteos de viernes o aunque no jueguen con tanta frecuencia, cuando lo compran, adquieren más de tres cupones.

El supercupón fin de semana tiene una base de jugadores habituales de un millón y medio, curiosamente cantidad similar que representan el número de jugadores esporádico de este producto.

La base de jugadores del bonocupón es de, aproximadamente, 350.000 personas, lo que representa un $1,2 \%$ en el total de jugadores de algún producto de lotería, y el público habitual y comprador frecuente del Bono viene a ser de 150.000 jugadores».

En la p. 16 precisa: «¿Qué día de la semana es el preferido?. Referente a los días de la semana en los que se suele comprar, el día del sorteo está muy relacionado con el momento de compra. El Cupón Diario en los cuatro días de lunes a jueves concentra su volumen de venta, destacando el miércoles como la jornada en el que más se compra. Los jugadores del Cuponazo adquieren, casi en su totalidad, entre el jueves y el viernes, un $22 \%$ y un $62 \%$ respectivamente, mientras que el Súper Cupón Fin de Semana lo hace un $41 \%$ el viernes y un 32\% entre el sábado y el domingo. En general el jueves es el día en el que más juegos y loterías se consumen, al coincidir varios sorteos y existir la proximidad de otros, como son el Cupón Diario, el Cuponazo de Viernes, la Lotería de Jueves, la Primitiva de Jueves y Sábado y el Euromillones».

22 Vide Resolución de 27 de julio de 2006, de la Secretaría de Estado de Servicios Sociales, Familias y Discapacidad, por la que se dispone la publicación de los Textos Refundidos de los Reglamentos reguladores de las distintas modalidades y productos de juego de la ONCE (BOE de 5 de agosto, núm. 186), Anexo I, Apéndice 1.

Vide ONCE, “¿A qué les gusta jugar?”, Punto de Venta, 40, (2004), p. 15: «¿Qué perfil tienen los clientes del cupón diario?. Si se tiene en cuenta el sexo y edad en los jugadores que podríamos denominar ocasionales (aquellos que juegan una vez o menos a la semana), comprobamos que el $53 \%$ son mujeres y aunque los tramos de edad comprendidos entre 25 y 65 años representa un porcentaje de un $15 \%$ en cada uno, el público mayor de 65 años tiene un peso definitorio en este perfil de un $22 \%$. Para sintetizar, el perfil del jugador ocasional del cupón diario es mayoritariamente una mujer y un público mayor de 65 años. En cambio, el perfil del jugador de frecuencia alta y media es casi diez puntos por encima, el número de hombres que de mujeres, y un $60 \%$ son mayores de 40 años. Con todo, hay una base de clientes de unos 3.500 .000 que, o bien compran todos los días un cupón, o bien, aunque jueguen menos días a la semana, compran dos o más cupones».

En la p. 17 precisa: «¿Conoce nuestro público los premios del cupón y su precio?. El conocimiento que tienen los jugadores del precio y premios del cupón difiere según productos: el precio exacto del Cupón Diario lo manifestaron casi un 58\% de los consumidores de este cupón, frente al $41 \%$ que lo acertaron en el caso del Cuponazo, reconociendo no saber el precio del pro- 
La reforma del producto llevada a cabo, se ha basado fundamentalmente en una subida del premio a las cinco cifras y en la introducción de un gran premio a las cinco cifras más la serie, acompañada de una subida del precio unitario.

Los ingresos derivados de la venta del cupón de lunes a jueves han supuesto durante el año 2003 el 48,3\% de las ventas totales. Su cuota de mercado en el sector de juego público ha sido del $10,5 \%{ }^{23}$.

\section{B. Sorteo del cupón de los viernes (cuponazo), con un premio especial a un sólo cupón de 6.000 .000 de euros ${ }^{24}$.}

Otra reforma de gran calado fue la que posibilitó ofrecer un cupón los viernes para reducir la semana laboral de los vendedores a cinco días y que se comunica mediante la Circular no 45 de 4 de septiembre de 1985:

«En virtud del Acuerdo del Consejo General de la ONCE, adoptado en las sesiones del 10 de abril y 31 de mayo de 1985, los sorteos ordinarios del cupón pro-ciegos experimentarán diferente configuración todos aquellos cuya celebración coincida en viernes, a partir del 4 de octubre, inclusive, de 1985; razón por la que, a fin de desarrollar convenientemente en el marco de las normas reguladoras de la materia la puesta a la venta de los cupones correspondientes a dichos sorteos, esta Delegación General estima oportuno cursar las instrucciones e informaciones siguientes:

$1^{\circ}$. En base al carácter ordinario que reviste el sorteo del cupón en viernes, los cupones correspondientes se pondrán a la venta a partir de la celebración del sorteo inmediato anterior.

$2^{\circ}$. Las comisiones a obtener por los vendedores lo serán en igual cuantía que las obtenidas en los restantes sorteos ordinarios, teniendo derecho a percibir el 25 por ciento de comisión por la venta de 140 cupones en cada sorteo con valor facial de 100 pesetas unidad y el 15 por ciento por todos aquéllos que expensan sobre los 140 antes citados. [...]».

ducto del viernes hasta un 39\%. El importe del Supercupón Fin de Semana lo desconoce un $62,6 \%$. Si hablamos de los premios, tenemos que en el caso del Cupón Diario lo desconocen hasta un $79 \%$, un $82,8 \%$ en el caso del Cuponazo y hasta un 90,5\% el Supercupón Fin de Semana».

${ }^{23}$ Vide Memoría de la Dirección General de la ONCE, 2003.

${ }^{24}$ Vide Resolución de 27 de julio de 2006, de la Secretaría de Estado de Servicios Sociales, Familias y Discapacidad, por la que se dispone la publicación de los Textos Refundidos de los Reglamentos reguladores de las distintas modalidades y productos de juego de la ONCE (BOE de 5 de agosto, núm. 186), Anexo I, Apéndice 2. 
Por parte del Consejo de Protectorado se determina la cantidad máxima de emisión por sorteo, la cantidad destinada a premios, la distribución de premios por emisión y el precio del cupón.

La introducción de un sorteo de viernes especial el primer viernes de cada mes desde comienzos del año 2003, no obtuvo los resultados esperados, motivo por el cual se optó en octubre por realizar una reforma de producto para todos los viernes del mes que si ha alcanzado un resultado más satisfactorio ${ }^{25}$.

El cuponazo del viernes ha obtenido unas ventas que representan el $38,5 \%$ de los ingresos del cupón y el 8,4\% de las ventas del sector de juego público.

\section{Sorteo del cupón de "Fin de Semana"26.}

La Comisión Permanente del Consejo General de la Organización Nacional de Ciegos, en el ejercicio de las facultades que le corresponden en virtud del Acuerdo General entre el Gobierno de la Nación y la ONCE en materia de cooperación, solidaridad y competitividad para la estabilidad de futuro de la ONCE, y en virtud de lo establecido en el artículo 7.3 del Real Decreto 358/1991, de 15 de marzo, modificado por el Real Decreto 1200/1999, de 9 de julio, tomó el Acuerdo de fecha 25 de septiembre de 2003, que suprimió el sorteo de primer fin de semana inmediato siguiente al primer viernes de cada mes y su sustitución por el producto denominado "Sorteo de Fin de Semana", a partir del 1 de enero de 2004.

Mediante dicho Acuerdo, la Organización simplifica y unifica los sorteos de fin de semana existentes hasta ese momento: "Fin de semana" y "Fin de semana inmediato siguiente al primer viernes de mes", que pasan a denominarse "Sorteos de Fin de Semana", a partir de la fecha indicada.

De conformidad con los términos del Acuerdo del Consejo de Ministros de 5 de marzo de 1999, con las facultades del Consejo de Protectorado de la

25 Vide Memoria de la Dirección General de la ONCE, 2003.

${ }^{26}$ Vide Resolución de 27 de julio de 2006, de la Secretaría de Estado de Servicios Sociales, Familias y Discapacidad, por la que se dispone la publicación de los Textos Refundidos de los Reglamentos reguladores de las distintas modalidades y productos de juego de la ONCE (BOE de 5 de agosto, núm. 186), Anexo I, Apéndice 3. 
ONCE previstas en el art. 8.3.d) del Real Decreto 358/1991, de 15 de marzo, modificado por el Real Decreto 1200/1999, de 9 de julio, y con el Acuerdo del Consejo de Protectorado de la ONCE de 29 de febrero de 2000 sobre procedimientos y criterios de control de las modalidades de juegos autorizadas a esa Entidad, y previa verificación de la Comisión Permanente del Consejo de Protectorado, realizada en su reunión de 13 de octubre de 2003, se procedió a dar publicidad, como garantía de los derechos de los consumidores, a la nueva estructura de los sorteos de fin de semana del cupón de la ONCE, con efectos de 1 de enero de 2004, mediante la Resolución de la Secretaría General de Asuntos Sociales de 13 de octubre de 2003 (BOE de 18 de noviembre, núm. 276).

La determinación que efectúa el Consejo de Protectorado es idéntica a la expresada en el apartado anterior. Sus ventas representan el 10,2\% de los ingresos del cupón ${ }^{27}$.

\section{Abono semanal: bono-cupón ${ }^{28}$.}

La forma de comercialización denominada "Abono Semanal" consiste en un cupón, preimpreso o emitido por terminal de punto de venta, válido para todos los sorteos de carácter periódico que se celebren durante un período de siete días naturales.

El título representativo del abono semanal será un documento que contendrá un único número y su serie, figurando las fechas de los sorteos para los cuales es válido, así como el precio total del cupón.

El "Abono semanal" es un producto que se extiende única y exclusivamente a una semana; por tanto, la ONCE no garantiza, en ningún caso, la continuidad de la numeración destinada a este producto durante períodos superiores a la semana, la disponibilidad continuada de ningún número, así como tampoco su suministro periódico al mismo agente-vendedor. El Abono Semanal adopta como nombre comercial: "Bono-cupón”.

27 Vide Memoria de la Dirección General de la ONCE, 2003.

28 Vide Resolución de 27 de julio de 2006, de la Secretaría de Estado de Servicios Sociales, Familias y Discapacidad, por la que se dispone la publicación de los Textos Refundidos de los Reglamentos reguladores de las distintas modalidades y productos de juego de la ONCE (BOE de 5 de agosto, núm. 186), Anexo I, Apéndice 4. 


\section{E. Otras formas de participación en varios productos o sorteos de un mismo producto distintos del abono semanal.}

También se contempla en la Resolución de 27 de julio de 2006, de la Secretaría de Estado de Servicios Sociales, Familias y Discapacidad, por la que se dispone la publicación de los Textos Refundidos de los Reglamentos reguladores de las distintas modalidades y productos de juego de la ONCE (BOE de 5 de agosto, núm. 186), Anexo I, Apéndice 5, la existencia de esta posibilidad.

\subsubsection{Lotería instantánea de boletos de la ONCE: rasca y gana, siete de la suerte, tres de seis cantidades, tres en raya a un euro y tres en raya a dos euros.}

De acuerdo con el Real Decreto 1336/2005, de 11 de noviembre, por el que se autoriza a la ONCE a la explotación de una lotería instantánea o presorteada, por el Real Decreto 358/1991, de 15 de marzo, de Reordenación de la ONCE, en redacción dada por los Reales Decretos 1200/1999, de 9 de julio, y 1359/2005, de 18 de noviembre, así como sus vigentes Estatutos, la ONCE está autorizada para comercializar una lotería de ámbito nacional denominada genéricamente como «lotería instantánea o presorteada», atribuyéndose a la ONCE la dirección, organización y explotación de dicha lotería en los términos establecidos en el Real Decreto 1336/2005.

El Consejo General de la ONCE está facultado por la normativa vigente para adoptar libremente cuantas medidas comerciales precise para la explotación de esta modalidad de lotería, siempre dentro de los límites establecidos por el citado Real Decreto 1336/2005 en cuanto al precio del boleto, el porcentaje de premios asignado por cada serie y el volumen máximo de venta y emisión.

La principal característica de esta lotería es la utilización, como soporte físico, de boletos emitidos en papel en los que una parte de cada boleto, denominada área de juego, esté cubierta con una capa de látex, que al rascarla descubre al concursante el premio. La comercialización de los productos de esta modalidad de juego se podrá realizar asimismo mediante la utilización de todos aquellos soportes informáticos, tecnológicos o de comunicación que existan o que puedan existir en el mercado, que presten una garantía plena a los consumidores y a la protección de los menores de edad, de acuerdo con la legislación vigente.

La comercialización de los boletos físicos de la lotería instantánea se realizará por medio de los agentes vendedores de la ONCE, y sin perjuicio de su 
distribución a través de otros canales, en los términos que prevea la normativa aplicable.

Esta modalidad presenta cinco tipos de productos con diferentes mecánicas de juego, precio y estructura de premios que han sido enumerados en el epígrafe y cuya regulación pormenorizada efectúa la Resolución de 27 de julio de 2006, de la Secretaría de Estado de Servicios Sociales, Familias y Discapacidad.

\subsubsection{Juego activo y su producto denominado "El Combo" ${ }^{29}$.}

\section{A. Su origen: la Resolución de la Secretaría de Estado de Servicios Sociales, Familias y Discapacidad de 29 de junio de 2004.}

La Resolución de la Secretaría de Estado de Servicios Sociales, Familias y Discapacidad de 29 de junio de 2004 (BOE de 11 de agosto, núm. 193) ${ }^{30}$ dispuso la publicación del reglamento regulador del nuevo juego activo de la Organización Nacional de Ciegos Españoles, denominado "El Combo", cuya justificación es la siguiente:

«El actual marco de ordenación de las actuaciones de la ONCE en materia de juego se encuentra regulado [...].

Conforme al mismo, el Consejo General de la ONCE está facultado para iniciar el desarrollo de nuevas modalidades de juego, de naturaleza activa o pasiva distinta del cupón, como instrumentos que permitan asegurar la competitividad en el mercado y poder alcanzar el volumen máximo de ventas autorizado a la Organización, con el objetivo de asegurar su esta-

29 Vide diario El País de 16 de octubre de 2004, "La ONCE estrena un juego para los sábados": «La Organización Nacional de Ciegos Españoles (ONCE) pone a la venta este fin de semana El Combo, un juego activo cuyo primer sorteo se realizará el sábado 23 de octubre, único día de la semana en el que hasta ahora no había un juego de la ONCE. El juego, resultado del acuerdo firmado en febrero entre el Gobierno y la ONCE, está formado por siete bolas: seis agrupadas en forma de triángulo y una adicional, denominada Combola. Hay que seleccionar un número del 0 al 9 para cada una de las seis bolas del triángulo y uno o más números del 1 al 11 para la Combola. Se pueden realizar apuestas múltiples. El juego costará un euro y se destinará a premios el $50 \%$. La previsión de ingresos es de cuatro millones por sorteo».

30 Vide Resolución de la Secretaría de Estado de Servicios Sociales, Familias y Discapacidad de 15 de julio de 2005, que da publicidad a la modificación de determinados aspectos del Reglamento regulador de "El Combo" de la ONCE (BOE de 10 de agosto, núm. 190). 
bilidad institucional y el cumplimiento de sus obligaciones sociales y económicas, presentes y futuras.

Asimismo, corresponde al Consejo de Protectorado de la ONCE verificar, con carácter previo a su explotación comercial, que las condiciones de las modalidades de juego concedidas y autorizadas a la ONCE se ajustan a los términos establecidos en el mencionado marco de ordenación de los juegos de azar autorizados a la ONCE, ordenando su publicación como garantía de los consumidores.

En cumplimiento de las anteriores previsiones, el Consejo General de la ONCE ha adoptado acuerdo de fecha 6 de mayo de 2004 sobre: «Aprobación de un nuevo juego activo denominado "El Combo", y su Reglamento", que ha sido verificado por el Consejo de Protectorado de la ONCE en su reunión ordinaria de 29 de junio de 2004. [...]».

Y en cuyo preámbulo se precisa:

«[...]. La comercialización del juego se realizará mediante boletos preimpresos y boletos emitidos por terminales de punto de venta o mediante la utilización de todos aquellos soportes informáticos, tecnológicos o de comunicación que existan o que puedan existir en el mercado, que presten una garantía plena a los consumidores y a la protección de los menores de edad, de acuerdo con la legislación vigente. Para la introducción de estos nuevos soportes se aprobará, en su momento, una modificación en el presente Reglamento, en el que se contendrá la regulación de los nuevos aspectos necesarios para su implantación plena. [...]».

En este sorteo se destina a premios el cincuenta por ciento de la recaudación de cada uno de los sorteos. Existen dos tipos de premio: premio de cuantía fija y premios de cuantía variable. Ninguno de los premios, excepto el bote, será acumulativo, debiendo abonar la ONCE al concursante el importe del premio superior que resulte del boleto. El precio de los boletos será de un euro por apuesta en un boleto, en el caso de apuestas múltiples, el precio del boleto será de un euro por cada uno de los números que el concursante haya elegido para la bola adicional.

\section{B. Reglamento regulador del juego activo denominado "El Combo".}

Tal y como establece el art. 7 del Real Decreto 358/1991, de 15 de marzo, modificado por el Real Decreto 1200/1999, de 9 de julio, y por el Real Decreto 1359/2005, de 18 de noviembre, el Consejo General de la ONCE puede adoptar, 
dentro del marco establecido en el vigente Acuerdo con el Gobierno de la Nación, cuantas actuaciones sean precisas en materia de régimen de sorteos de juego.

Así el Consejo General, tras analizar la situación del juego El Combo y las posibilidades que brinda el citado Acuerdo General, ha modificado el reglamento regulador del este juego, mediante el cual se modifican las categorías de los premios y se adaptan los procedimientos para el cálculo del escrutinio a las nuevas categorías. Su texto definitivo se encuentra en la Resolución de 27 de julio de 2006, de la Secretaría de Estado de Servicios Sociales, Familias y Discapacidad.

La venta de los boletos de El Combo se inició el 25 de septiembre de 2005, celebrándose el primer sorteo el 1 de octubre. El sorteo tiene carácter periódico y se celebrará una o más veces por semana. Cada sorteo se celebrará el día, hora y lugar publicado por la ONCE con la antelación suficiente para que el público pueda conocerlo, teniendo el sorteo siempre carácter público.

Podrán existir dos sistemas de admisión o validación de apuestas para "El Combo": la adquisición de un boleto preimpreso y la emisión de un boleto mediante el sistema de validación informática que podrá realizarse en los lugares y en la forma establecida reglamentariamente.

Las categorías de premios son las siguientes:

Categoría 1a. Pleno más combola: se aciertan los números asignados en el sorteo de las seis bolas del triángulo, colocadas en su orden, y el número asignado en el sorteo a la bola adicional.

Categoría 2a . Pleno: se aciertan los números asignados en el sorteo a las seis bolas del triángulo, colocadas en su orden.

Categoría 3 $3^{a}$. Triple: se aciertan los números asignados en el sorteo a las tres bolas de la fila base del triángulo, colocadas en su orden.

Categoría 4⿳亠丷a . Doble: se aciertan los números asignados en el sorteo a las dos bolas de la fila del centro del triángulo, colocadas en su orden.

Categoría 5 ${ }^{\mathrm{a}}$. Reintegro: se acierta el número asignado en el sorteo a la bola colocada en el vértice del triángulo.

Categoría $6^{\text {a }}$. Combola: se acierta el número asignado en el sorteo a la bola adicional. 


\section{Elementos.}

Sus elementos se determinan en la Resolución de 27 de julio de 2006, de la Secretaría de Estado de Servicios Sociales, Familias y Discapacidad, por el que se dispone la publicación de los textos refundidos de los reglamentos reguladores de las distintas modalidades y productos de juego de la ONCE.

\subsection{El documento o título.}

\subsubsection{Tipo de soporte y formas de comercialización.}

Me remito a lo expuesto en el apartado clasificación, donde doy cuenta de la existencia de distintos tipos de soporte, y de las distintas formas de comercialización.

\subsubsection{Contenido de la impresión ${ }^{31}$.}

\section{A. Anverso.}

El cupón deberá llevar impreso en su anverso, como mínimo: numeración, serie o series, precio y fecha del sorteo ${ }^{32}$. El boleto deberá incluir la apuesta o apuestas, su importe y la fecha o fechas de los sorteos en los que participa $^{33}$.

${ }^{31}$ Vide Real Decreto 3389/1981, de 29 de diciembre, Ministerio de Hacienda (BOE de 27 de enero, núm. 23), características de los billetes de la lotería nacional, art. 1: «El párrafo $3^{\circ}$ del artículo $7^{\circ}$ de la Instrucción General de Loterías queda redactado como sigue: "Las fracciones de los billetes de la Lotería nacional habrán de llevar impresos, como mínimo, los siguientes detalles: A) En el anverso; numeración, serie, número de fracción, precio, fecha de celebración del sorteo, en forma destacada del texto, sello en seco del Servicio u otras marcas de garantía y firma del Jefe de éste. Se incluirán, además, impresiones de fondos de seguridad y numeración secundaria codificada. B) En el reverso; relación de los premios ofrecidos, billetes de que consta la emisión, extracto de los artículos de la Instrucción de mayor interés para el jugador en cuanto al pago de premios y, por último sello de la Administración de Loterías expendedora. Como atributo suplementario el papel podrá incorporar marcas o sustancias que faciliten su identificación».

32 Vide Resolución de 27 de julio de 2006, de la Secretaría de Estado de Servicios Sociales, Familias y Discapacidad, por la que se dispone la publicación de los Textos Refundidos de los Reglamentos reguladores de las distintas modalidades y productos de juego de la ONCE (BOE de 5 de agosto, núm. 186), Anexo I, art. 1 f).

${ }^{33}$ Idem, Anexo II, art. 3.6.a) y Anexo III, art. 3.7. 


\section{B. Reverso.}

En el reverso del cupón deberá llevar impreso la relación de los premios, así como un extracto de los artículos del reglamento de mayor interés para el jugador, excepto en aquellos formatos, que por razones de espacio, o por englobar varios sorteos no sea posible detallar las diferentes estructuras de premios. En este supuesto se hará referencia al reglamento regulador del sorteo del cupón de la Organización Nacional de Ciegos Españoles, que las contiene, y a los lugares físicos y electrónicos donde puede obtenerse dicho reglamento. En el reverso del cupón también se indicará que los programas de los sorteos se publican en el $\mathrm{BOE}^{34}$.

En el reverso del boleto se hará referencia al reglamento y a los lugares físicos y electrónicos donde puede obtenerse dicho reglamento así como la indicación de que los programas de los sorteos se publican en el Boletín Oficial del Estado ${ }^{35}$.

\section{Cupones o boletos emitidos por terminal de punto de venta ${ }^{36}$.}

En el caso de los cupones o boletos emitidos por terminal de punto de venta, el documento deberá incluir, además, de un código de control, el número indentificativo del vendedor, el número identificativo del terminal y la fecha y la hora de la operación. Dicho código de control será único y biunívoco con la participación, para cada cupón o boleto emitido por el terminal punto de venta, y será asignado por el Sistema Central de Control de Juego de la ONCE en base a un algoritmo preestablecido. La biunicidad se predica respecto de la correspondencia única y absoluta entre los datos grabados para ca-

\footnotetext{
${ }^{34}$ Idem, Anexo I, art. 1.g).

35 Idem, Anexo II, art. 3.6.b).

36 Vide ONCE, "CAUT: Centro de Atención a Usuarios con TPV", Punto de Venta, 40, (2004),
} pp. 8-11: «Desde que se inició el servicio el 1 de diciembre de 2003, estamos intentando mejorarlo. Las llamadas entran en el nivel uno y dependiendo de la dificultad de las mismas, quedan cerradas, se soluciona el problema o directamente se pasan donde correspondan, a los centros o a incidencias de comunicación que es el nivel dos. Las incidencias más comunes son las de comunicación, el mantenimiento de material, etc.

La llamada puede derivar al nivel dos y todo ello queda registrado en un entorno web, el cual controlo desde mi puesto verificando lo que está entrando en el centro, si son consultas, incidencias, anulaciones, bloqueos, etc., lo cual es muy importante porque desde ahí nosotros vamos viendo qué tipo de dudas pueden tener los vendedores, las carencias más destacadas, las inciden- 
da participación en el Sistema Central de Control de Juego de la ONCE y los reflejados en cada cupón emitido por el terminal punto de venta. Este código de control quedará guardado, antes del sorteo, en ficheros auditables y firmados con firma electrónica reconocida, de tal forma que los mismos se puedan aportar y sirvan como prueba documental en cualquier procedimiento. De los ficheros antedichos serán expedidas varias copias de seguridad. La falta o manipulación del código de control supone la pérdida de validez del cupón o boleto emitido por terminal punto de venta, sin derecho a ningún premio ni al reintegro del importe del cupón o boleto.

\subsection{Las series.}

Para cada uno de los sorteos de la ONCE, se pondrán a la venta series de cupones de cien mil números correlativos, cada una desde el 00.000 al 99.999 . Para cada sorteo se asignarán números y series específicos que serán puestos a la venta por cada uno de los soportes antes enunciados, de forma diferenciada.

En el caso de los boletos, el número que contiene cada serie se fijará en el apéndice de cada producto. El número de series que componen la emisión global de un producto será variable.

cias que más se generan, las irregularidades de comunicación, etc. Pasamos todo lo detectado al CAUT de comunicaciones que nosotros desde aquí controlamos, verificamos a través de un "entorno visión", que los datos y transacciones que está realizando el vendedor son correctos, que le llegan todos los detalles, y comprobamos que puede trabajar. Si no es así, pasamos un informe o incidencia a Telefónica para que realice un estudio de cobertura al vendedor en esa zona en concreto. $[\ldots]$.

Normalmente la formación se imparte en tres días, el primero de ellos solemos explicar lo que es el TPV. El segundo día la práctica de la aplicación, recibiendo la formación en el mismo equipo y el tercer día trabajan con un compañero que tiene experiencia, e inclusive al final de la mañana pueden atender alguna llamada. Durante tres o cuatro días están trabajando con el asesoramiento de una persona, para ayudarles si lo necesitan. [...].

CONSULTAS E INCIDENCIAS. Se pueden dar varios casos al recibir una llamada. Si no se identifica el número de teléfono entrante, el operador le solicita al interlocutor que le facilite sus datos. Existe diferencia entre consulta e incidencia. La consulta se responde desde el operador de nivel 1 y la incidencia se deriva al centro o al operador de nivel 2. La consulta puede ser de cualquier tipo: de teclado, lector de código de barras, de la pantalla, de los perfiles, de la batería, etc.

$\mathrm{Si}$ el vendedor comunica una incidencia, se le pregunta de que tipo es. Un ejemplo de ello es que el transformador se le ha roto, incidencia habitual al principio. Se detecta la causa y se corrige. Cuando el vendedor manifiesta este tipo de incidencia, se averigua si le ha ocurrido otras veces, ya que puede ser que el TPV lo tenga conectado a un voltaje menor del que corresponda, esta cuestión iría automáticamente al centro. A los centros se les deja un plazo de 24 horas para subsanar la incidencia, si no la cierra, se le reclama qué ocurre. Si se ha cancelado, se habla con el vendedor para averiguar si dicha irregularidad está subsanada, si es así, se da por cerrada la misma. [...]». 


\subsection{Precio y estructura de premios.}

Se determinará individualmente, una vez aprobada la propuesta por el Consejo General de la ONCE, de acuerdo con lo previsto en los Estatutos de la Organización, adjuntándose en cada caso, como apéndice numerado al reglamento regulador del sorteo.

En todos los cupones o boletos deberá figurar expresamente impreso el precio para cada sorteo, con excepción del correspondiente al Abono Semanal, en que aparecerá el precio total y los sorteos para los cuales es válido.

El precio de los cupones o boletos emitidos por terminales de punto de venta será el resultante de la suma del precio individual de cada una de las participaciones que contenga. En el cupón o boleto emitido por terminal de punto de venta, figurará el precio total de todas las participaciones que contenga.

Los premios de los cupones o boletos emitidos por terminales de punto de venta son la suma de los premios correspondientes a cada uno de los números y series de los sorteos contenidos en cada cupón. La distribución de estos premios se regirá por lo preceptuado en los apéndices correspondientes a cada tipo de sorteo. El pago se hará efectivo conforme a las prescripciones señaladas en el reglamento regulador del sorteo.

\subsection{El sorteo.}

El sorteo es el acto formal de extracción reglada de números y serie o series, que determinarán los premios, según el juego de que se trate.

Me remito al apartado grupo normativo regulador, desarrollado en páginas posteriores.

\subsection{Derechos de los compradores.}

\subsection{1. ¿Cómo garantizar los derechos de los consumidores?.}

A los efectos de garantizar los derechos de los consumidores, en el reverso del cupón o boleto figurará un extracto del reglamento regulador del sorteo de la ONCE, debiendo reflejarse las principales categorías premiadas, los plazos de caducidad, las formas y lugar de pago, la indicación de que los programas de los sorteos se publican en el "Boletín Oficial del Estado" y todos aquellos aspectos que la ONCE entienda de interés a fin de garantizar tales derechos. Los consumidores podrán presentar en los centros de la ONCE cual- 
quier reclamación sobre las deficiencias en la prestación del servicio. Asimismo el comprador tendrá a su disposición el reglamento del cupón o boleto en los centros de la ONCE y en la página de internet "http//www.once.es".

En aquellos formatos que por razones de espacio, o por englobar varios sorteos no sea posible detallar las diferentes estructuras de premios, se hará referencia al reglamento regulador del sorteo del cupón o boleto de la ONCE, que las contiene, y a los lugares físicos y electrónicos donde puede obtenerse dicho Reglamento.

\subsubsection{Reclamaciones y recursos.}

Contra los actos de la Organización en materia de sorteos los interesados podrán formular reclamación ante el Director General de la ONCE, en el plazo de un mes a contar desde el día siguiente a la fecha de la notificación del acto.

Contra la resolución del Director General, los interesados podrán interponer recurso del alzada ante el Consejo General de la ONCE, cuando la cuantía de la reclamación sea igual o inferior a treinta mil euros (30.000 euros), o ante el Consejo de Protectorado, en caso contrario; recursos que agotarán la vía administrativa previa a la jurisdiccional. El plazo máximo de interposición de este recurso será de un mes, a contar desde el día siguiente a la fecha de la notificación de la resolución del Director General.

Tanto en fase de reclamación como de recurso de alzada ante el Consejo General de la ONCE se dictará resolución expresa. El plazo máximo para la resolución de las reclamaciones y recursos por los órganos de la ONCE será de dos meses, contados a partir de su presentación. El plazo indicado quedará interrumpido por cualquier acto propio del procedimiento incluida la práctica de elementos probatorios, cuya duración estimada resulte superior a un mes. La suspensión del procedimiento y la subsiguiente ampliación del plazo será acordada mediante resolución expresa y notificada al interesado, sin que, en ningún caso, la suspensión en sí misma conlleve una demora superior a tres meses. Transcurrido el plazo de duración del procedimiento o ampliado, en su caso, sin que por la ONCE se hubiese dictado resolución, el recurso deberá entenderse desestimado, con la excepción de que el recurso de alzada ante el Consejo General de la ONCE se hubiese interpuesto contra la desestimación por transcurso del plazo sin que el Director General de la ONCE hubiese dictado una resolución sobre la reclamación presentada, en cuyo caso se deberá entender estimado el recurso. 
Las reclamaciones relativas a cupones o boletos emitidos por terminal de punto de venta deberán contener la identificación del código de control representativo de la participación.

\section{Grupo normativo regulador.}

\subsection{Evolución legislativa.}

El régimen jurídico básico y la evolución del sorteo del cupón, y el nacimiento de los boletos lo podemos evidenciar en las siguientes disposiciones:

- Reglamento de funcionamiento económico-administrativo aprobado inicialmente por el Consejo Superior de Ciegos el 11 de diciembre de 1945.

- Real Decreto 358/1991, de 15 de marzo, de reordenación de la ONCE ${ }^{37}$.

- Estatutos de la Organización Nacional de Ciegos Españoles ${ }^{38}$.

De su análisis se desprende una articulación jurídica que denota una concepción radicalmente distinta a la establecida inicialmente. En primer lugar, la evolución origina que no sólo se regule el sorteo del cupón, sino también de los demás juegos de azar autorizados en los Acuerdos entre el Gobierno de la Nación y la ONCE. Segundo, el régimen de autorizaciones establece los límites máximos, dentro de los cuales la ONCE podrá desarrollar la gestión de las distintas modalidades de juego, pasivo o activo, de que se trate. Respecto al cupón, dichos límites máximos se referirán al volumen máximo de emisión y ventas anuales, porcentaje máximo de premios, precios máximos del cupón y los criterios para su actualización, sorteos extraordinarios y cuantas otras cuestiones sean precisas para un correcto ejercicio por la ONCE de la concesión estatal del cupón. Tercero, la autonomía adquirida por la corporación de derecho público de carácter social posibilita que el Consejo General de la ONCE pueda adoptar las decisiones que sean precisas, por razones organizativas,

${ }^{37}$ Modificado por el Real Decreto 1200/1999, de 9 de julio (BOE de 28 de julio) y Real Decreto 1359/2005, de 18 de noviembre, por el que se modifica el Real Decreto 358/1991, de 15 de marzo, por el que se reordena la Organización Nacional de Ciegos Españoles (BOE de 1 de diciembre).

${ }^{38}$ Modificados por la Orden TAS/2533/2006, de 27 de julio (BOE de 2 de agosto, núm. 183): «La disposición final primera del Real Decreto 1359/2005, establece que el Consejo General de la ONCE propondrá al Consejo de Protectorado, en el plazo de seis meses a partir de su entrada en vigor, la aprobación de las modificaciones de los Estatutos de la organización que sean precisas para adaptarlos al citado Real Decreto. 
económicas o comerciales, sin efectuar consulta alguna, siempre que se desarrollen dentro de los límites máximos establecidos en el acuerdo autorizador. Cuarto, las distintas reformas efectuadas sobre el cupón y el sorteo, hacen que hoy podamos hablar de una modalidad de lotería de carácter nacional que ha adquirido la "mayoría de edad".

\subsection{Una innovación muy reciente: los textos refundidos de los reglamentos re- guladores de las distintas modalidades y productos de juego de la ONCE.}

Para determinar la situación actual hay que hacer referencia a la ya citada Resolución de 27 de julio de 2006, de la Secretaría de Estado de Servicios Sociales, Familias y Discapacidad.

Dicha disposición es publicada en cumplimiento de las previsiones establecidas en las disposiciones vigentes y en cumplimiento de las mismas, el Consejo General de la ONCE ha adoptado un Acuerdo de fecha 21 de julio de 2006, por el que se aprueban los «Textos Refundidos de los Reglamentos reguladores de las distintas modalidades y productos de juego de la ONCE», dirigidos a poner a disposición de los consumidores unos textos actualizados y consolidados que faciliten el conocimiento de las condiciones de estas modalidades y productos de juego, con lo que se refuerza la garantía de sus derechos.

Los citados textos refundidos han sido verificados por el Consejo de Protectorado de la ONCE en reunión de 27 de julio de 2006, procediendo su publicación en el BOE como garantía de los consumidores.

\subsection{La autorización del sorteo del cupón pro-ciegos y de la gestión de otros juegos de azar que explota la ONCE.}

\subsubsection{Concesión estatal del cupón prociegos ${ }^{39}$.}

En el proceso de reforma estatutaria y de conformidad con el mencionado marco regulador, corresponde al Consejo General de la ONCE aprobar, por mayoría absoluta, la propuesta de modificación de sus Estatutos, que deberá ser aprobada por el Consejo de Protectorado, y se dispondrá su publicación en el "Boletín Oficial del Estado".

En cumplimiento de las anteriores previsiones, el Consejo de Protectorado de la ONCE, en reunión celebrada el 27 de julio de 2006, ha aprobado los nuevos Estatutos de la organización. El texto aprobado, incorpora los ajustes al acuerdo del Consejo General de la Entidad de fecha 11 de mayo de 2006, derivados del proceso de tramitación, aprobación y publicación ante el Consejo de Protectorado».

39 Vide Estatutos de la Organización Nacional de Ciegos Españoles, art. 93. 
Con el fin de proporcionar recursos económicos suficientes para el cumplimiento de los fines sociales de la ONCE y, como una vía más, para la creación de empleo para las personas ciegas y con deficiencia visual grave, mediante el Decreto de 13 de diciembre de 1938 que creó la Organización Nacional de Ciegos Españoles y el reglamento aprobado por Orden del Ministerio de la Gobernación de 28 de octubre de 1939, el Estado Español concedió a la ONCE la explotación en exclusiva, en el ámbito nacional, de una modalidad de juego de carácter pasivo denominada cupón prociegos, concesión que ha sido desarrollada por diferentes normas posteriores y que permanece vigente, a tener de las previsiones contenidas en el RD 358/1991.

\subsubsection{Marco normativo de la autorización de otras modalidades de juego ${ }^{40}$.}

Como complemento de la concesión estatal del cupón prociegos, y al amparo del grupo normativo regulador expuesto, el Consejo de Ministros ha otorgado a la ONCE autorización para explotar otras modalidades de juego:

a) El Consejo de Ministros de 5 de marzo de 1999, aprobó el «Acuerdo General entre el Gobierno de la Nación y la Organización Nacional de Ciegos Españoles (ONCE), en materia de cooperación, solidaridad y competitividad para la estabilidad de futuro de la ONCE», mediante el cual se autorizó a la ONCE a explotar la modalidad de juego activo.

b) Esta autorización ha sido confirmada y ampliada por el acuerdo del Consejo de Ministros de 27 de febrero de 2004, que aprobó el «Acuerdo General entre el Gobierno de la Nación y la Organización Nacional de Ciegos Españoles (ONCE), en materia de cooperación, solidaridad y competitividad para la estabilidad de futuro de la ONCE para el período 2004-2011».

c) En el futuro, resultarán de aplicación las previsiones contenidas en el Acuerdo General entre el Gobierno de la Nación y la ONCE, vigentes en cada momento, aprobado por el Consejo de Ministros conforme a la habilitación legal citada.

Asimismo, el Real Decreto 1336/2005, de 11 de noviembre, por el que se autoriza a la Organización Nacional de Ciegos Españoles la explotación de una lotería instantánea o presorteada, ha concedido a la ONCE la posibilidad de comercializar una modalidad de juego, de ámbito nacional, denominada lotería instantánea.

40 Vide Estatutos de la Organización Nacional de Ciegos Españoles, art.94. 


\subsubsection{Régimen jurídico del proceso de autorización ${ }^{41}$.}

El régimen autorizador lo determina el grupo normativo regulador que ha sido expuesto.

El nuevo marco de ordenación de las actuaciones de la ONCE en materia de juego, sustituye al antiguo sistema de autorizaciones casuísticas, establece uno nuevo de límites preestablecidos claros, dentro de los cuales la ONCE actúa sin la necesidad de autorizaciones puntuales, que sólo serán imprescindibles cuando se precise superar los límites establecidos.

El Consejo General deberá ser oído con carácter previo al acuerdo sobre las autorizaciones relativas al régimen de sorteos del cupón prociegos, así como de otras modalidades de juego de naturaleza activa o pasiva distinta de las del cupón, que definirán con precisión los términos, alcance y duración de las respectivas autorizaciones.

Tal y como ha sido expuesto, corresponde al Consejo de Protectorado resolver los recursos contra los actos de la organización, agotando la vía administrativa previa a la jurisdiccional, en materia de las diferentes modalidades de juegos autorizados a la ONCE, cuando la cuantía del asunto supere la cantidad establecida o la que pudiera fijarse en el futuro por la legislación aplicable.

Con el objeto de conseguir una mayor competitividad de la ONCE, mediante el uso flexible de instrumentos económicos y comerciales eficientes con capacidad de adaptación a las circunstancias del mercado y conseguir un adecuado control público y rigor en la gestión, el régimen de autorizaciones se basa en la fijación de criterios e indicadores que establecen los límites máximos, dentro de los cuales la ONCE puede desarrollar la gestión de sus juegos, y que no puede sobrepasar sin la previa y expresa autorización del Consejo de Ministros.

Los límites establecidos estarán referidos, entre otros, a: volumen máximo de emisión y ventas anuales para el conjunto de las modalidades de juego comercializadas por la ONCE; porcentaje máximo de premios y precio máximo del cupón en los productos de la modalidad cupón prociegos; volumen máximo de emisión y venta anual, precio máximo del boleto o soporte unitario y porcentaje máximo de premios en los productos de la modalidad lotería instantánea; volumen máximo de venta anual, precio máximo de la apuesta y porcentaje máximo de premios en los productos de la modalidad juego activo.

41 Vide Estatutos de la Organización Nacional de Ciegos Españoles, art. 95. 


\section{Cuota de participación del cupón en el juego ${ }^{42}$.}

La cuota de participación del cupón de la ONCE respecto de la cantidad total destinada a juegos de azar por los españoles ha sufrido oscilaciones a lo largo del tiempo. Si se observa la secuencia temporal desde 1970 hasta 1984, se aprecian dos tendencias claramente diferenciadas. En primer lugar se produce una reducción de la cuota, leve pero sostenida, desde 1970; tal descenso pasa a ser muy pronunciado a partir de 1981. Ello no se debe tanto a incrementos negativos en los niveles de ingresos como a la entrada en el mercado de los juegos legalizados en 1977. Así, si descontamos las máquinas recreativas (subsector con más de un 50 por ciento de participación), la cuota de mercado del Cupón en 1984 sería más del 14 por ciento (un 4,57\% sobre el total). Por otro lado, se observa una fuerte recuperación desde 1984, año en que duplica su cuota de mercado. Tal tendencia se ha venido manteniendo en los años posteriores ${ }^{43}$.

En épocas más reciente, después de la atonía mostrada en 2002 por el mercado de juego público en España, en el que creció sólo un 0,2\% en moneda corriente y que supuso, por tanto, un descenso en la recaudación en términos reales, el año 2003 ha significado el inicio de la recuperación de este mercado, con un crecimiento del 5,7\%.

El mayor crecimiento en términos porcentuales se ha producido en las apuestas deportivas, que suben a un ritmo del $16,7 \%$ tras la fuerte caída que experimentaron en 2002, un $13,9 \%$. Por su parte el resto de loterías activas (lotos), continúan su tendencia de aumento de cuota en el mercado de juego público, representando ya en 2003 el 28,4\% del mercado total frente al 23,9\% que obtenían en el año 98.

A pesar de lo anterior la lotería pasiva (Cupón y Lotería Nacional) continúa siendo la lotería de mayor aceptación comercial en España con un 66,5\% de cuota de mercado.

42 Vide Memoria de la Dirección General de la ONCE, año 2003: Evolución del mercado de juego público en España.

43 Vide Negociado de Estudios del Juego, "El cupón de la ONCE: evolución socio-histórica, situación actual”, Cuadernos de Información Jurídica, 41, (1989), pp. 84-85. 
El gasto por habitante y año en el mercado de juego público español durante el año 2003 ha sido de 248 euros, creciendo 8,5 euros con respecto al año anterior.

No se disponen de datos oficiales sobre la evolución de las recaudaciones de juego privado (fundamentalmente máquinas tipo $\mathrm{B}$, bingos y casinos), por lo que no se puede hacer ninguna valoración acerca de la evolución de la totalidad del mercado del juego en España.

\section{Publicidad ${ }^{44}$.}

La evolución progresiva y próspera experimentada por la ONCE desde 1984 hasta nuestros días, se debe, en gran parte, a la intensa y brillante campaña publicitaria desarrollada por la Entidad en prensa, radio, televisión y otros medios de comunicación. Este organismo y la lotería nacional son las dos únicas empresas dedicadas al juego que pueden hacer publicidad.

La ONCE que en 1982 no aparecía en el ranking de las empresas que invertían más de cien millones de pesetas al año en publicidad, en 1985 pasa a gastar 1.053 millones de pesetas y ya se situó en el décimo lugar del ranking de las empresas con mayores gastos en esta rama propagandística, mientras que los gastos en publicidad de las loterías públicas situaban al Ministerio de Economía y Hacienda en el puesto número 47. En 1986 la ONCE se situó en el puesto 17, en tanto que el mencionado Ministerio ocupaba el puesto 18.

En 1987 la ONCE gasta 3.054 millones de pesetas para promocionar El Cuponazo $^{45}$ (2 de octubre de 1987), haciendo un gran despliegue publicita-

\footnotetext{
${ }^{44}$ Sirva como ejemplo el siguiente fragmento de canción que fue tarareado por toda la sociedad: Tema: "No me llames iluso". Grupo: La cabra mecánica.

Fragmento: "No me llames iluso porque tenga una ilusión, si la suerte es caprichosa el amor es ciego, y con el tuyo me ha tocado el cupón”.

Vide ONCE, ¿Qué es la ONCE?, ONCE, Madrid, 1988, p. 11. Vide Diego A. MANRIQUE, "La campaña del sorteo extraordinario de la ONCE, que hoy ofrece Antena 3, se convierte en el fenómeno de la temporada", Diario El País (versión electrónica), 16-8-2003.

45 Vide Roberto GARVIA SOTO, La organización nacional de ciegos. Un estudio institucional, Centro de Estudios Avanzados en Ciencias Sociales, Madrid, 1993, p. 250, donde rebaja la cantidad de promoción del cuponazo a 1.500 millones de pesetas. En todo caso señala: «Esta cantidad suponía casi el doble de la inversión en publicidad que la realizada en todo el ejercicio anterior. En 1987 la ONCE invirtió más de 2.000 millones de pesetas, el doble que el ONLAE, y, para hacerse una idea, sólo un 3\% menos que Coca-Cola».
} 
rio, que dio por resultado que las ventas de cupones subieran un 37 por ciento; y la entidad de no videntes, que había recaudado 156.000 millones de pesetas en 1987, obtuvo unas ganancias de 233.000 millones de pesetas al año siguiente. El colectivo de los privados de vista se ha convertido en una de las primeras empresas de inversión publicitaria en España ${ }^{46}$.

Quizás nos de una idea la importancia que se otorga a la publicidad y los magníficos resultados cosechados por la ONCE, el siguiente ejemplo:

«En septiembre de 1987, Televisión Española insertó machaconamente, a todas horas del día y de la noche, un imaginativo y espectacular anuncio publicitario. Una cámara de cine recorría de un extremo a otro de la capital de España siguiendo a una interminable columna humana que empezaba en el Puente de Segovia, continuaba por la Puerta del Sol y atravesaba de punta a punta, la plaza de toros de Las Ventas.

Esta hilera fue rodada en varias tomas. Para ello se utilizaron más de quinientos extras y una cámara que se deslizaba a lo largo de un cable de 1,5 kilómetros de largo, que, al parecer, conducía al Museo del Prado. Sorpresivamente, la columna de centenares de hombres y mujeres concluía poco antes. Frente a las puertas de la primera pinacoteca española, una de las más importantes del mundo, un modesto puesto de venta de la ONCE era el causante del barullo que colapsaba Madrid.

La ONCE se gastó 100 millones en producir el anuncio. Contrató al equipo de "efectos especiales" del conocido director de las películas más taquilleras del mundo, como E.T. o Indiana Jones, Steven Spielberg. La realización la puso en manos del británico Eduard Macklin, con el camarógrafo Vernon Layton, ambos reputados profesionales del mundo del celuloide. Por último, Nacho Cano, del grupo musical Mecano, se encargó de la banda sonora del spot.

Los ciegos lograron así el impacto publicitario previsto. El mensaje del anuncio que no desvelaba en ningún momento la marca del producto comercial que trataba de vender, creó una inusitada expectación en la opinión pública española. El efecto se consiguió de golpe, con una frase lapidaria pronunciada por una voz en off que cerraba los treinta segundos

46 Vide Jesús MONTORO MARTÍNEZ, Los ciegos en la historia, Tomo V, o.c., p. 566. 
de emisión: "El próximo 1 de octubre en este país va a ocurrir algo que traerá cola" ${ }^{47-48}$.

Durante el año 2003 (únicos datos de los que dispongo) se han realizado seis campañas de publicidad diferentes: nuevo cupón diario 2003, cuponazo 2003, institucional ("queda mucho por hacer"), supercupón fin de semana, campaña de verano (cupón especial de 16 de agosto) y navidad ("la abuela"). El reconocimiento del sector profesional quedó plasmado en las distinciones a la campaña de verano que fue finalista al gran AMPE de oro y obtuvo el de plata en radio, así como el Premio Internacional a la Eficacia Publicitaria. Por su parte la campaña de navidad obtuvo un AMPE de plata en TV y un oro en el Festival Iberoamericano de publicidad. Pero, premios aparte, la publicidad ha influido positivamente en el índice de simpatía del público en general hacia la institución y ha alcanzado una notoriedad muy superior a la de épocas precedentes ${ }^{49}$.

47 Vide José DÍAZ HERRERA, La rosa y el bastón, 2aㅡ ed., Ediciones Temas de Hoy, Planeta, Madrid, 1992, pp. 89-90.

48 Vide diario El País de 30 de mayo de 1999, "El 14º Festival de Publicidad premia la campaña del cupón de la ONCE: «El gran ganador del 14º Festival de Publicidad de San Sebastián celebrado los días 28 y 29 de mayo ha sido un anuncio de lotería. La campaña para la ONCE, realizada por la agencia Slogan, ha merecido un triple galardón: el Gran Premio del Festival en las categorías de televisión y radio y el Sol de Oro, también de televisión. En ella, un dicharachero joven, de nombre Julio Canal, invita al telespectador a comprar un cupón que por la irrisoria cantidad de 200 pesetas y un poco de suerte puede convertir los sueños más caros en realidad».

49 Vide "Al descubierto: entrevista a César Palacios García. Director General Adjunto de Economía y Juego", Punto de venta, 40, (2004), p. 5: «Es más importante la información que traslada el vendedor al público sobre el producto, que las acciones publicitarias. La campaña tendrá una duración determinada, pero, al final, el vendedor en la calle es nuestro mejor altavoz para la difusión de nuestros productos y para dárselos a conocer al cliente. Tenemos que conseguir que los 23.000 vendedores, junto con todos los que formamos parte de la ONCE, seamos capaces de trasladar y transmitir a los clientes la misma información, de esta manera, será mucho más duradero en el tiempo y llegará a muchas más personas». 
A la vez constituye un medio ideal para propiciar la consecución de distintos objetivos. Bien se trataba de conseguir convertir cada anuncio en una entrevista de empleo $^{50}$, o concienciar sobre la labor social ${ }^{51}$.

50 Vide Antón ÁLVAREZ RUIZ, La función social de la publicidad de la ONCE, Escuela Libre Editorial, Madrid, 2003, pp. 109-110, donde reproduce la campaña: "Preparados, listos, ya", anuncio: "Locutoras":

«Chica 1: Soy, Luisa.

Chica 2: Yo soy Carmen.

Chica 1: Buscamos trabajo.

Chica 2: !Las dos!.

Chica 2: Soy locutora de radio.

Chica 1: Yo también soy locutora de radio.

Chica 1: Cinco largos años estudiando juntas.

Chica 2: !Fueron siete!.

Chica 1: Bueno, pero fue bastante duro ¿no?.

Chica 2: !Uff! (Risas).

Chica 1: Hablo inglés ...

Chica 2: Francés ...

Chica 1: Italiano ...

Chica 2: !Uy!, italiano, dice, arrivederci. (Risas).

Chica 1: A veces hacemos footing juntas.

Chica 2: !Siempre juntas!. (Muestran las muñecas de las manos atadas, como los corredores ciegos).

Chica 1: Bueno, lo dicho, que buscamos trabajo.

Chica 2: Pero una de nosotras lo va a tener más difícil.

Chica 1: Porque una de las dos es ciega.

Chica 2: Es ella.

Chica 1: !Anda!, es ella.

Chica 2: No, es ella.

Locutor: Y ¿qué más da cuál sea ciega?. Son dos personas que han recibido la formación adecuada. Listas para integrarse ya a un equipo de trabajo.

Rótulo: Preparados. Listos !Ya!».

Dicho anuncio tuvo su continuación en la campaña: "Queda mucho por hacer", donde las dos locutoras ya han encontrado trabajo, y donde la que es ciega indica que no lo va a celebrar, pues queda mucho por hacer, y donde el locutor cierra con el siguiente texto: «Quedan muchas personas con discapacidad, perfectamente formadas para trabajar. Ahora queda que empresas privadas e instituciones públicas, las contraten. Y queda que todos sigamos comprando el cupón de la ONCE para continuar creando empleo».

${ }^{51}$ Ibídem, p. 202, donde expone el texto del anuncio "La casa encantada", octubre de 1988: «Música

Niño: Abuelo, !qué calle tan bonita!.

Abuelo: Es la calle de los hombres que sirven a los hombres. Mira, ellos ponen paz en nuestras calles (policias) y ellos, paz en el espíritu (monja y sacerdote); esas cuidan de nuestro cuerpo (enfermeras) y aquella adiestra nuestra mente (profesora).

Niño:¿Y ese señor tan serio?. 


\section{Los juegos de la ONCE contribuyen decisivamente a la generación de em- pleo y de recursos.}

\subsection{El epicentro del sistema.}

Sin duda alguna, el epicentro de generación de empleo lo constituye la venta del cupón y otros juegos autorizados. Es preciso resaltar que con los recursos económicos obtenidos (memoria del año 2003), se financia no sólo un amplio sistema de servicios sociales, sino también el mantenimiento de 91.691 puestos de trabajo en el conjunto del Grupo ONCE (46.667 empleos directos y 45.024 empleos indirectos) lo que supone el 0,54\% del empleo total en España. Con un dato muy relevante, como es que el $77 \%$ de dicho total corresponde a personas ciegas o con otros tipos de discapacidad. Además, con estos recursos, también se financia la Fundación ONCE. Y todo ello sin olvidar que la ONCE contribuye a la generación de riqueza nacional mediante su actividad económica que supone un $0,20 \%$ de PIB, y de las aportaciones a los ingresos públicos a través del pago de impuestos y cotizaciones a la Seguridad Social. Además, la ONCE se ha comprometido a crear 8.000 nuevos empleos hasta $2011^{52}$.

Esta opción, ha sido una constante en la trayectoria de la Organización, para propiciar la inserción laboral de los invidentes:

«En este punto son de mencionar, aparte de los Colegios a cargo de la Organización y que aparecen reseñados en otro epígrafe, las instituciones o centros a cargo de la misma y establecidos con la finalidad de proporcionar trabajo a todos aquellos afiliados que quieran o puedan realizarlos. En este sentido, la Organización Nacional de Ciegos tiene en marcha un plan que comprende aquellas formas de trabajo que se han considerado

Abuelo: !Oh!. Ese es la ley (juez).

Niño: Ah, la ley.

Abuelo: Estos están aquí para sacarnos las castañas del fuego (bomberos).

Niño: $Y$ aquel que no lleva uniforme ¿de que sirve?.

Abuelo: Es de la ONCE. Y enseña a muchos a vivir como los demás, ¿iverdad, señor?

Ciego: !Ajá!.

Niño: ¿Y que enseñan aquí?.

Ciego: En esta casa enseñamos muchas, muchas cosas. Enseñamos a ver con las manos, a caminar sin luz, a escribir sin lápiz ... . Y, desde freír un huevo sin ver la sartén hasta jugar al fútbol ... . !Al fútbol con cascabeles!.

Niño: !Jo! es como una casa encantada.

Ciego: Encantada de servir».

${ }^{52}$ Vide Memoria de la Dirección General de la ONCE, 2003. 
más adecuadas a las circunstancias de sus afiliados. Los trabajos que con arreglo a este plan se han organizado son los siguientes:

1) Telefonía: Se halla en periodo de montaje una Escuela de Telefonía, cuya instalación está prevista en el nuevo edificio sito en Madrid, calle Prim, 3.

2) Fisioterapia: La enseñanza de esta especialidad está ya iniciada en las Escuelas oficiales de Ayudantes Técnico-Sanitarios; en el futuro continuará en la Escuela de Fisioterapia de la Organización, cuya creación está oficialmente autorizada.

3) Mecánica ligera: La instrucción para esta especialidad se llevará a cabo en un Centro de Formación Profesional Industrial próximo a instalarse por la Organización.

4) Artesanía: Funciona actualmente en Madrid un pequeño taller escuela de Artesanía para ciegas adultas.

5) Avicultura: Estas enseñanzas se proporcionan en el Colegio "Inmaculada Concepción" de Madrid, donde funciona una Granja-Escuela; en esta Granja se instruye a los alumnos para poder llevar por sí mismos una explotación avícola familiar.

A fin de conseguir la rehabilitación social de los invidentes, antes de proporcionarles cualquier tipo de rehabilitación laboral se ha incluido en el plan de referencia la creación de un Centro de Rehabilitación social.

La Organización tiene previsto, una vez proporcionado el correspondiente adiestramiento a sus afiliados, la colocación de los mismos en adecuados puestos de trabajo en empresas y entidades diversas, o bien proveyendo de primeras materias a los afiliados que realicen trabajos en su domicilio y dando salida a los productos por ellos fabricados.

Otra manera de llevar a cabo la finalidad de rehabilitación laboral de los invidentes, según el plan previsto, es la de crear centros de trabajo de la propia organización, estando prevista la creación de un taller mecánico anexo al Centro de Formación Profesional Industrial, así como la creación sucesiva de otros centros de trabajo de distintas especialidades.

Está en marcha también la instalación de granjas avícolas rurales de tipo familiar, regidas por ciegos que han recibido el adecuado entrenamiento en la Granja-Escuela del Colegio "Inmaculada Concepción”. La Organización facilita préstamos para establecer dichas granjas, las cuales quedan durante el período de amortización del préstamo bajo el asesoramiento técnico y contable de la organización» 53 .

53 Vide Ramón MARTÍN MATEO, Guía de actividades públicas asistenciales. La asistencia social como servicio público, Ministerio de la Gobernación, Madrid, 1967, pp. 164-165. 
Es decir, se han buscado y se buscan otras alternativas que complementen las opciones a las que puede acceder este colectivo, y esta voluntad manifestada reiteradamente, no es nueva:

«Por lo que se refiere a la integración laboral, últimamente la ONCE ha apostado fuerte por abrir nuevas puertas como alternativa a la venta de cupón, a través del fomento de la formación profesional y académica, de la política de diversificación empresarial y de conciertos con empresas e instituciones públicas. Todo ello desde la convicción de que participar en el mercado laboral es el primer paso para la integración plena, pero también porque se siente responsable del futuro profesional de miles de titulados, que han confiado y apostado por un futuro profesional como alternativa a la venta del cupón, que de no lograrlo, verían frustradas sus expectativas en un mercado laboral competitivo que además no siempre manifiesta suficiente receptividad $»^{54}$.

Entre las distintas salidas profesionales que se han auspiciado desde la propia organización debo destacar las siguientes: las escuelas de telefonía de la Organización Nacional de Ciegos ${ }^{55}$, la escuela de fisioterapia de la Organización Nacional de Ciegos Españoles ${ }^{56}$, el centro de formación y rehabilita-

${ }^{54}$ Vide ONCE, Las necesidades en servicios sociales de los afiliados a la ONCE, ONCE, Madrid, 1993, p. 14.

55 Vide Roberto GARVIA SOTO, La organización nacional de ciegos. Un estudio institucional, o.c., p. 126: «El plan Sotillos no fue un plan improvisado. Se visitó el centro de instrucción industrial para ciegos de Letchworth (Inglaterra), para estudiar su réplica en España. Se tenía conocimiento de que en Alemania trabajaban 800 ciegos como telefonistas, en Inglaterra 300, y en Francia 600. Además, la Caixa se había adelantado a la propia ONCE en España, al crear el año anterior la primera escuela de telefonía para ciegos». Vide Jesús MONTORO MARTÍNEZ, Los ciegos en la historia, Tomo V, o.c., pp. 242-244.

${ }^{56}$ Ibídem, pp. 244-246. Tiene especial interés la Orden del Ministerio de Educación Nacional de 11 de abril de 1964 (BOE de 12 de mayo, núm. 114):

«La Presidencia del Consejo Superior de Ciegos se ha dirigido a este Departamento, solicitando la creación de una Escuela de Especialización de Fisioterapia en la que los ciegos españoles puedan cursar las enseñanzas, previa la realización, con dispensa de determinadas asignaturas, de los estudios de Ayudantes Técnicos Sanitarios, exigidos por el Decreto del 26 de julio de 1957, que regula la mencionada especialidad. Esta petición, justificada por la necesidad de facilitar el acceso a la vida laboral de un gran número de invidentes, en los que la experiencia viene demostrando que están dotados de hábiles condiciones para el ejercicio del masaje, merece ser recogida por el Estado que, siguiendo el ejercicio de Instituciones análogas, que funcionan en otros países, debe adoptar las normas oportunas para que aquéllos puedan cursar estas enseñanzas en las condiciones que sus especiales circunstancias físicas aconsejen. De esta forma, el aprovechamiento de sus facultades para los trabajos en los que están especialmente dotados, ejercerá una influencia decisiva en su aspecto personal, familiar y social. 
ción profesional e industrial ${ }^{57}$, así como otras alternativas, que ya he expuesto y que ponen de manifiesto el enorme esfuerzo de los invidentes y de la Orga-

En atención a dichas consideraciones, previo Informe de la Comisión Central de Estudios de Ayudantes Técnicos Sanitarios y dictamen del Consejo Nacional de Educación, este Ministerio ha dispuesto:

$1^{\circ}$. Autorizar a la ONCE para la creación de una Escuela de Fisioterapia adscrita a la Organización y vinculada a la Facultad de Medicina de la Universidad de Madrid, en la que se cursarán los estudios de esta especialidad por los ciegos que ingresen en la misma.

$2^{\circ}$. Para iniciar los estudios de dicha especialidad en la Escuela, los interesados deberán cursar, previamente, los de Ayudantes Técnicos Sanitarios en cualquiera de las Escuelas creadas por el Departamento, quedando dispensados de cursar las enseñanzas correspondientes a las disciplinas de Obstetricia y Ginecología, Medicina, Cirugía de Urgencia y las prácticas de autopsia. La aprobación de los estudios de Ayudante Técnico Sanitario en las condiciones indicadas, no supondrá el derecho a la expedición de título académico correspondiente.

$3^{\circ}$. Las enseñanzas que se cursen en esta Escuela se ajustarán al plan de estudios y programas previstos en el Derecho de creación de la especialidad, del 26 de julio de 1957 y sus disposiciones complementarias.

$4^{\circ}$. En la escuela de Fisioterapia, cuya creación se autoriza por la presente Orden, se empleará el mismo instrumental y material que en las restantes escuelas oficiales de la especialidad.

$5^{\circ}$. Los alumnos que hayan aprobado los dos cursos de la especialidad y hayan realizado las prácticas reglamentarias de hospital, obtendrán el Diploma de Ayudante Técnico de Fisioterapia que, de acuerdo con lo establecido en el Decreto de 26 de julio de 1957, será expedido por el Departamento. Los Diplomas de Ayudantes de Fisioterapia, que se expidan a los mencionados alumnos, habilitarán, exclusivamente, para practicar la modalidad terapéutica de los masajes, y así se hará constar en aquéllos.

[...]». Vide Roberto GARVIA SOTO, La organización nacional de ciegos. Un estudio institucional, o.c., p. 126: «[...]. El oficio de masajista tampoco era una novedad. Se sabía que ésta era "la profesión de los ciegos” en Japón. Es España ya se intentó en los años 30 cuando, voluntariamente, el doctor Bartrina dio algunas clases de "Kinesiterapia" a un limitado número de ciegos. El mismo Tovar era masajista. La rehabilitación para ciegos adultos ya era desde los años 50 en los países más desarrollados un área de atención privilegiada. El plan de Sotillos pretendía, en suma, aprovechar las experiencias de otros países en la rehabilitación e integración de los ciegos al mundo laboral».

57 Vide Jesús MONTORO MARTÍNEZ, Los ciegos en la historia, Tomo V, o.c., pp. 246-248. Sobre el mismo merece la pena transcribir el informe dado por el Consejo Superior de Ciegos con fecha 4 de junio de 1968: «La Organización Nacional de Ciegos ha creado en Madrid el Centro Especial de Rehabilitación y Formación Profesional e Industrial para la formación laboral de los ciegos y, en lo posible, de los semiciegos, y su incorporación a la industria privada, capacitándoles en régimen continuado durante todo el año y con jornada similar a la que es común en la industria siderometalúrgica, para su posterior empleo en la industria, en paridad con los videntes.

La incorporación de los aspirantes tiene lugar en cualquier fecha del año, a medida que se producen vacantes en las 20 plazas existentes.

La formación dura seis meses, en general, dependiendo la duración real de la capacidad del alumno, que, tras un dictamen social ha de ser comprobada en los dos primeros meses, como condición imprescindible para continuar el curso. Durante esta enseñanza laboral los alumnos que viven en régimen de internado completo por cuenta de la Organización Nacional de Ciegos, percibiendo mensualmente una pequeña cantidad de dinero para sus gastos menores. 
nización para lograr su inserción en el mundo laboral. Aun así, el cupón y los demás juegos autorizados constituyen el epicentro de la generación de empleo en la ONCE.

También debo manifestar, una vez más, que la generación de recursos por parte de la ONCE es un elemento clave que permite incidir en la búsqueda de opciones profesionales y en la prestación de servicios a los afiliados ${ }^{58-59}$.

Cuando un solicitante tenga familia que dependa de él, indicará las circunstancias concurrentes como consecuencia de tal dependencia, a fin de que el caso pueda ser considerado por la Jefatura de la ONCE. La formación que se obtiene, avalada por los alumnos ya colocados, comprende especialistas en ensamble y montaje, verificación, máquinas-herramientas (taladros, roscadoras, prensa, torno revólver, etc.).

Se evitará la admisión de solicitudes de personas que no acrediten propósitos de perseverancia, y no estén dotadas de las aptitudes necesarias.

La Organización Nacional de Ciegos se cuidará de gestionar la colocación de los alumnos, mas obtenida ésta, quedarán durante dos años privados de toda actividad remunerada dentro de la Obra Tiflológica.

Los profesionales procedentes del CERFPI y las empresas donde se hallen empleados, contarán con todo el apoyo que pueda prestar la Organización para el mayor éxito de su actividad.

Las condiciones de admisión para el ingreso en el CERFPI son éstas:

a) Ser afiliado o tener defecto de visión que impida su empleo en circunstancias corrientes.

b) Haber cumplido 18 años antes de la fecha de incorporación al centro y no sobrepasar los 35 en la fecha de terminación del curso. Para aquéllos que acudan al centro después de haber desempeñado alguna actividad laboral siempre que las empresas donde trabajaron estén dispuestas a admitirlos, se podrá arbitrar alguna forma más elástica en relación con la edad de admisión.

c) No padecer enfermedad infectocontagiosa ni defecto físico o psíquico que le impida realizar vida en común, o el normal desarrollo de las enseñanzas en el centro.

De momento no se admiten mujeres. [...]».

${ }^{58}$ Vide diario El País, 6 de marzo de 1999, "La ONCE crea nuevos sorteos para financiar 20.000 empleos": «La ONCE se ha comprometido con el Gobierno a crear 20.000 puestos de trabajo para discapacitados, no sólo visuales, en los próximos 10 años. Y a cambio ha recibido carta blanca para entrar en el mercado de juegos activos, como la primitiva, a partir del 2002, y la posibilidad de incrementar hasta un $10 \%$ anual el precio del cupón y de realizar sorteos extraordinarios desde el próximo año. [...].

Una comisión formada por representantes de cada parte hará el seguimiento de los compromisos. $[\ldots]$ »

59 Vide diario El País, de 16 de febrero de 2004, p. 68, "La ONCE y el Gobierno han alcanzado un acuerdo para asegurar los ingresos y la labor de la organización hasta 2011. El acuerdo, según explica el actual presidente de la ONCE, Miguel Carballeda, prevé el lanzamiento de nuevos juegos de azar y la renovación del popular cupón": «[...], desde julio pasado, ha cerrado un acuerdo con el Ministerio de Trabajo para asegurar los ingresos de la organización hasta 2011. Relativamente satisfecho -el Gobierno no ha permitido a la ONCE participar en la nueva lotería europea-, Carballeda destaca que el acuerdo permitirá renovar el cupón, lanzar juegos activos tipo primitiva y participar al 50\% con el Estado en una nueva lotería instantánea. A cambio, la ONCE (47.302 empleados 
directos, 41.000 indirectos y 65.000 afiliados ciegos) se compromete a crear en el periodo $8.000 \mathrm{em}$ pleos estables para discapacitados. El acuerdo prevé que la ONCE venda por importe de $2.400 \mathrm{mi}-$ llones de euros en 2004, 2.700 millones en 2005, 3.000 millones en 2006 y 3.300 en 2007. A partir de 2008, los ingresos previstos sean de 3.300 millones incrementados en el IPC más tres puntos.

Pregunta. ¿Qué sucede si no se alcanzan los objetivos de ventas recogidos en el acuerdo?

Respuesta. Si no alcanzamos el objetivo, el acuerdo establece tres mecanismos. Uno es compartir la lotería europea recién puesta en marcha. Apostamos por ello y vamos a seguir peleándolo porque se supone, además, que si no alcanzamos los objetivos será por las consecuencias de esa lotería europea. El segundo mecanismo sería ampliar nuestras posibilidades de juego: ampliar emisiones y alguna opción nueva como un sorteo extraordinario en Navidad, como ya se hizo en 1984, 1985 y 1986. La tercera opción es algo que en principio no queremos, y es una subvención directa del Ministerio de Hacienda, porque queremos seguir viviendo de nuestro trabajo.

[...].

P. En los últimos años, la ONCE sufre una caída de ventas. ¿Cómo prevén frenarla?.

R. El acuerdo está muy bien redactado para evitar dificultades de interpretación, como nos venía ocurriendo. Ahora tenemos que desarrollar aquellos juegos más idóneos en función de la competencia europea. Tratando por supuesto, de que no afecten a otras opciones como el cupón ordinario, que nos ha permitido recaudar casi 2.300 millones de euros.

P. ¿A qué nuevos juegos se refiere?.

R. Nosotros veníamos reclamando la posibilidad de hacer un bote. Ahora se nos permite hacerlo con el cupón habitual. Dedicaremos una parte del conjunto anual de los premios a generar un bote. Aún tenemos que decidir a qué producto y qué día lo ponemos. Además, se ha ampliado la posibilidad de entrar en el juego activo tipo primitiva, bonoloto, el juego que está dando mejor resultado en el mundo. El acuerdo de 1999 limitaba esa posibilidad de emisión al 10\% de lo que Loterías y Apuestas del Estado (LAE) recaudara. No se podía competir. Ahora, esa posibilidad se ha ampliado. Podremos vender por valor de 600 millones de euros, 100.000 millones de las antiguas pesetas.

P. Pero vender ese tipo de juego será complicado para un invidente ...

R. Sí, pero el acuerdo establece que la ONCE podrá vender parte de ese juego activo de forma preimpresa.

P. Estudian también alguna forma de lotería instantánea ...

R. Esa posibilidad se nos puso sobre la mesa por parte del Ministerio [de Trabajo] ya avanzada la negociación que empezó en septiembre. La Administración quiere sacar ese juego y llegamos al acuerdo de compartirlo al $50 \%$ en obligaciones, derechos y ventas.

P. ¿A qué se ha debido la caída de ventas de los últimos tiempos?.

R. Ha ocurrido en todo el mundo, en Europa y también en España. Los juegos pasivos han tenido una caída importante porque han irrumpido otros juegos más ágiles, más atractivos. En España tenemos el ejemplo de la lotería tradicional.

P. ¿Por qué esa negativa reiterada a darles entrada en el Euromillones [la lotería europea]?.

R. No lo tengo claro. Nos explicaron algo sobre la dificultad de entendimiento con los socios ... . Eso no es así, porque cuanto más se venda en el conjunto, mejor para todos, más se reparte. Puede ser que tengan dificultades internas ... .

P. Sus ingresos, según los presupuestos de 2004, no crecen mucho y, sin embargo, las cantidades para servicios sociales si crecen de forma significativa. A medio plazo, en cualquier empresa eso significaría problemas.

R. Tanto el acuerdo de 1999, como el actual dice que la ONCE está obligada a crecer en servicios sociales al menos lo que crezca en ventas. Es verdad que hemos venido creciendo en servicios por encima y con resultados negativos. Pero tenemos cada vez más actividad (65.000 afiliados) y hemos mejorado la atención. 


\subsection{Distribución de recursos.}

En lo que se refiere a la distribución de recursos se puede establecer el siguiente cuadro comparativo ${ }^{60}$ :

- Distribución de ingresos brutos del cupón "La Hispalense" (siglo XX, años 30).

\begin{tabular}{|l|l|}
\hline Pago de premios al cupón & $25 \%$ \\
\hline Pago de premios a la colección & $20 \%$ \\
\hline Comisión para el vendedor & $40 \%$ \\
\hline Destinado a la caja social & $15 \%$ \\
\hline
\end{tabular}

P. En los presupuestos, destacan el propósito de controlar gastos. ¿No los controlaban ya?.

R. Creo que estamos en un nivel adecuado de control del gasto. Los niveles de control son absolutos por parte del Consejo General y el Consejo del Protectorado.

P. Pero la plantilla de 23.000 vendedores ¿no está sobredimensionada?.

R. Es un tema muy complejo, porque de los 23.000 vendedores hay una parte que no son productivos; estamos hablando de una plantilla con discapacidad. Se debería considerar. Pero tenemos la obligación de que sean lo más rentables posibles, porque si no, vamos a la bancarrota directamente. Estamos depurando y buscando las mejores opciones para nuestros vendedores.

P. Supongo que también para el grupo de empresas [la ONCE controla un holding de 15 empresas en sectores diversos, desde hoteles a seguros, pasando por seguridad y limpieza con 13.000 empleados] que una vez fue tan activo.

R. Se ha encargado un análisis del grupo empresarial que ha demostrado que su estado de salud es perfecto. Hemos tenido etapas muy deficitarias, pero hemos saneado esta situación y las empresas están, una a una, en una situación adecuada. Queremos un buen plan estratégico y buscar compañeros de viaje en algunos sectores, alguien que nos aporte recursos, medios y conocimientos, porque buscar compañeros pobres ..., ese viaje no vale. En hoteles por ejemplo, buscamos un buen socio, pero sin perder identidad. Se han acercado a nosotros en el tema de hoteles y en el de seguridad.

[...].

P. La ONCE seguirá dedicándose, en primer lugar, a las personas ciegas y después si es posible, a los demás discapacitados.

R. Claro. El 3\% de nuestro ingreso bruto por la venta del cupón se destina a las personas con otras discapacidades. Defendíamos que esto se mantuviera, porque es la solidaridad de la ONCE con el sector de la discapacidad.

P. ¿Qué compromiso tiene la ONCE con el mundo de la discapacidad?

R. Es su motor.

P. También es la que manda.

R. Y la que ayuda a coordinarse. Había que unir el sector. [...]».

${ }^{60}$ Vide Antón ALVAREZ RUIZ, La función social de la publicidad de la ONCE, o.c., pp. 64-65. Los datos y porcentajes aproximados correspondientes al cupón, que varían según el tipo de sorteo, corresponden al año 1999. 
- Distribución actual de ingresos brutos del cupón de la ONCE.

\begin{tabular}{|l|c|}
\hline Pago de premios & $50 \%$ \\
\hline Gastos de explotación & $25 \%$ \\
\hline Destinado a servicios sociales & $20 \%$ \\
\hline Destinado a la Fundación ONCE & $5 \%$ \\
\hline
\end{tabular}

La evolución de la sociedad y de la ONCE se ha correspondido con una diferente distribución de ingresos, pues en la actualidad los vendedores son trabajadores por cuenta ajena (gastos de explotación) y aparecen instrumentos nuevos como la Fundación ONCE, a la que también se destinan ingresos.

En todo caso debo destacar que desde el punto de vista de los ingresos, por ejemplo el ejercicio 2003, ha venido caracterizado por un descenso en las ventas del cupón del 3,52\%, con respecto al año 2002, que ha supuesto una recaudación de 2.299,34 millones de euros por este concepto. A pesar de este descenso, la ONCE se mantiene como el duodécimo operador de lotería del mundo y el segundo de los operadores europeos de lotería pasiva por detrás tan sólo de LAE.

Este descenso de recaudación, ha arrastrado a un resultado de explotación peor que el año anterior y que ha conducido a un excedente final del ejercicio de 7,8 millones de euros, lo que implicó una disminución de más de 39 millones de euros en este parámetro. Los resultados financieros y extraordinarios permitieron paliar este resultado, y consiguieron que no se incrementara el endeudamiento bancario, y que, sobre todo, se hayan podido sostener crecimientos razonables en la política de servicios sociales para afiliados, así como en las inversiones en inmuebles dedicados a prestación de servicios y al desarrollo informático de los sistemas de juego ${ }^{61}$.

\section{LA VENTA DE LAS MODALIDADES Y PRODUCTOS DE JUEGO.}

\section{Concepto.}

Es el acto por el cual se expende un cupón o boleto (me remito al concepto expuesto) mediante la oferta, diligencia y habilidad del vendedor, a cambio de una retribución pecuniaria en metálico, previamente determinada.

61 Vide Memoria de la Dirección General de la ONCE, 2003. 


\section{Naturaleza jurídica.}

La naturaleza jurídica de la operación consistente en la venta del cupón o boleto teniendo en cuenta la vinculación existente entre la ONCE y el comprador, es la correspondiente a un contrato aleatorio de apuesta ${ }^{62}$.

${ }^{62}$ Vide Rafael de LORENZO GARCÍA, "Naturaleza jurídico de la ONCE (IV)", Cuadernos de Información Jurídica, s/n, (1987), pp. 232-236:

«b) Clases de operaciones mercantiles. Se trata de precisar el objeto de la intervención del mediador, es decir, qué tipo de operaciones mercantiles, o mejor dicho, qué debe entenderse por tales. Según Ortega Prieto hay que entender por operación mercantil la conclusión de un negocio. "Es decir, la actuación de aquél ha de tener como objetivo el perfeccionamiento de un contrato, generalmente mercantil, entre la empresa para la que aquél presta sus servicios y una tercera persona o entidad".

A la búsqueda del esclarecimiento de la relación jurídica que une a la ONCE con sus clientes compradores del cupón, se hacen precisas unas puntualizaciones previas en torno a la posible configuración contractual de dicha relación.

El Código Civil regula en su artículo 1.790 y siguientes, la tipología de los contratos aleatorios definiéndolos como: "Por el contrato aleatorio, una de las partes, o ambas recíprocamente, se obligan a dar o hacer alguna cosa en equivalencia de lo que la otra parte ha de dar o hacer para el caso de un acontecimiento incierto, o que ha de ocurrir en tiempo indeterminado". El alea está constituido por la incertidumbre que provoca el acontecimiento incierto (al no saberse si se realizará o no) o porque no se sepa cuándo va a ocurrir. El alea origina una indeterminación sobre quién será el obligado a la prestación, en definitiva. El contrato existe desde el momento de su perfección si bien el nacimiento de las obligaciones está en función del alea misma. El contrato aleatorio es de carácter oneroso, sinalagmático y bilateral, no admitiéndose la rescisión por lesión. El mismo Código Civil regula específicamente en sus artículos 1.798 al 1.801 el contrato de juego o apuesta; lo importante es la apuesta en sí, de la que el juego es el instrumento o medio de producción artificial del alea.

El vínculo jurídico existente entre la ONCE y sus clientes compradores es de naturaleza contractual, concretamente como contrato aleatorio de apuesta. [...]

Como se verá, el juego de cupón pro-ciegos y las apuestas que las partes se cruzan, se ajusta perfectamente a los requisitos especiales del contrato aleatorio de juego o apuesta del Código Civil, produciéndose la perfección del contrato mediante la intervención del mediador (vendedor de cupón) en el acto de intercambio del cupón (que entrega el vendedor en nombre y por cuenta de la ONCE), a cambio del pago del precio del cupón unidad (que paga el comprador), de cuyo precio el vendedor del cupón percibe una comisión preestablecida. El contrato tiene virtualidad desde ese mismo momento si bien el nacimiento de las obligaciones derivadas de la apuesta (escala de premios) depende del acto mismo del sorteo (alea), en cuyo momento se sabrá con certeza quién es el obligado a dar o hacer lo pactado, es decir, si el número del cupón adquirido por el comprador coincide con el que aleatoriamente se extrae por el procedimiento del sorteo, tendrá derecho a percibir el premio prefijado y por tanto, la ONCE estará obligada a abonárselo; si dicha coincidencia no se produce, la ONCE queda libre de toda obligación y el comprador pierde el dinero apostado (cupones comprados).

Se observa nítidamente, que las obligaciones surgen entre la ONCE y sus clientes compradores en virtud de dicho contrato aleatorio consistiendo la labor mediadora del vendedor de cupón 
Sin embargo la STS de 26 de septiembre del 2000 (Ar. 9646), en el FD. Tercero, precisa el concepto de "expender", así como la "naturaleza de la entrega del cupón vendido", donde determina que no es un acto de mediación:

«[...]. En el tráfico mercantil actual, las operaciones que caracterizan a los representantes o mediadores de comercio o asimilados no son meras operaciones de expedición o entrega, sino contratos de venta o distribución al por mayor o al menos contratos que tienen por objeto un producto o servicio de cierta complejidad e importancia económica. La actividad de "expender" que define a los vendedores de cupones es, de nuevo según el Diccionario de la Real Academia, una actividad de venta "al por menor" o "al menudeo". La diligencia y la habilidad del vendedor son sin duda un factor importante de las ventas realizadas, pero la oferta del producto que el vendedor lleva a cabo no constituye propiamente un acto de "promoción" del mismo, que se suele llevar a cabo por medios publicitarios. Tampoco la entrega del cupón vendido es un acto de mediación entre la empresa y el cliente, en el sentido que tiene el término en la jurisprudencia civil; como recuerda una sentencia de la Sala I de este Tribunal Supremo de 19 de octubre de 1993 (Ar. 7744), en el contrato de mediación "la función del mediador está dirigida a poner en conexión a los que pueden ser contratantes", actividad que corresponde a operaciones comerciales de cierta importancia o dificultad (venta de un inmueble en el caso de la sentencia citada), pero que no es la desarrollada por los vendedores de cupones, ni tendría sentido desde el punto de vista económico en este segmento del tráfico mercantil».

\section{Clasificación.}

La clasificación se puede establecer en base a diferentes criterios.

\subsection{En virtud de quien realiza la venta.}

Atendiendo a la condición de la persona y sus características se puede diferenciar entre aquella realizada por personas sanas, invidentes, minusválidos de otro tipo, afiliados o no, etc. Además, cobra especial interés -por lo que tiene de clarificador- el nuevo artículo 110 de los Estatutos de la ONCE, que es-

en el perfeccionamiento de tales contratos entre ambas partes, actividad mediadora que se realiza en nombre y por cuenta de la Entidad sin quedar personalmente obligado ni responder del buen fin de la operación, es decir, de las obligaciones derivadas del nacimiento del contrato». 
tablece las relaciones jurídicas diferenciadas entre afiliados a la corporación de derecho público de carácter social y los trabajadores, en los siguientes términos:

«Uno. La relación jurídica de afiliación a la ONCE se regirá por lo dispuesto en los presentes Estatutos y, especialmente, en su Título I; y será compatible, pero diferenciada, de la relación jurídica laboral, cualquiera que sean los supuestos y circunstancias en que se encuentren; de conformidad con lo dispuesto, en general, en las leyes de aplicación y en las normas específicas aplicables a la ONCE y, en particular, el Convenio Colectivo en cada caso vigente.

Dos. La relación asociativa de afiliación a la ONCE es completamente independiente de la relación laboral que pudieran concertar los afiliados con la Organización a través de la celebración de contratos de trabajo. La relación de afiliación, nace, se desarrolla y se extingue de conformidad con lo establecido en los presentes Estatutos y en la normativa de desarrollo que pueda dictarse; en tanto que la relación laboral nace, se desarrolla y se extingue de conformidad con lo previsto en el Estatuto de los Trabajadores y, particularmente, por el Convenio Colectivo de la ONCE y su personal, en cada caso vigente. En el supuesto de que una misma persona ostente la doble condición de afiliado y trabajador de la ONCE, la extinción de la relación laboral no afectará a la vigencia de la relación de afiliación, ni viceversa.

La extinción de la relación laboral se ajustará, en todo caso, a la legislación laboral y al convenio colectivo aplicable a la misma, sin que puedan prevalecer más condicionamientos ni limitaciones que las que dichas normas prevean.

Conforme a la distribución competencial entre órganos jurisdiccionales establecida en la Ley Orgánica del Poder Judicial, los conflictos derivados del nacimiento y extinción de la relación de afiliación serán de la competencia del Orden Jurisdiccional Contencioso Administrativo; en tanto que los conflictos derivados de la relación laboral, serán de la competencia del Orden Jurisdiccional Social».

\subsection{En virtud de la modalidad de venta: fija e itinerante.}

La fórmula más habitual es la asignación al vendedor de un punto fijo: quiosco, esquina, plaza, etc., debiendo respetarse escrupulosamente los lugares asignados. Pero también es frecuenta la figura del vendedor que deambula de un lugar a otro ofreciendo el cupón. 


\subsection{En virtud de la tipología de los puntos o zonas de venta.}

La evidente evolución y transformación del mercado de juego, hace imprescindible la necesidad de adaptar la red de ventas y la estructura de los canales de distribución a las peculiaridades que en cada momento presente dicho mercado, así como a las circunstancias que lo rodean, ya sean internas o externas. Todo ello permite clasificar la venta del cupón en virtud de la tipología de los puntos o zonas de venta.

El punto o zona de venta es aquel lugar, emplazamiento o espacio abierto o cerrado, que la ONCE establece para realizar la venta del cupón y demás productos de juego, mediante la actuación profesional de los vendedores.

Con carácter general todo punto o zona de venta dispondrá de un área de influencia perfectamente delimitada, formando el conjunto un todo indivisible.

Los puntos o zonas de venta se clasifican del siguiente modo.

\subsubsection{Puesto de venta.}

Es aquel punto de venta fijo en la vía pública, que extiende sus posibilidades comerciales a su área de influencia, formando el conjunto un todo indivisible.

\subsection{2. Área de venta.}

Es aquella zona de venta de cobertura itinerante, circunscrita al área urbana o interurbana, sin que en la misma exista un punto fijo de venta.

\subsubsection{Quiosco.}

Es aquel punto de venta fijo, sito en la vía pública, donde se halla instalada una cabina del modelo autorizado por la ONCE, que extiende sus posibilidades comerciales a su zona de influencia, formando el conjunto un todo indivisible.

\subsubsection{Stand.}

Es aquel punto de venta fijo ubicado en un centro comercial, estación de ferrocarril o metropolitano, aeropuerto, etc., donde generalmente se halla 
instalado un quiosco o habitáculo homologado; si no fuera posible su instalación, se utilizará el expositor autorizado por la ONCE. En cualquier caso, todo stand tendrá también una zona de influencia que se determinará en función de las características del entorno donde esté ubicado.

\subsubsection{Local comercial.}

Es aquel punto de venta fijo ubicado en inmueble propiedad de la ON$\mathrm{CE}$, o del que ésta sea arrendataria, concesionaria o beneficiaria. En cualquier caso, todo local comercial tendrá también una zona de influencia que se determinará en función de las características del entorno donde esté ubicado.

\subsubsection{Ruta de venta.}

Se entiende por ruta de venta la cobertura de diversos municipios o varios núcleos de población de un mismo municipio, para lo cual, el vendedor necesita utilizar vehículo particular o transporte público para el ejercicio de la venta.

\subsection{En virtud del instrumento utilizado para participar en el sorteo: compra de un cupón/boleto o una transacción electrónica a través de terminales móviles con comunicaciones inalámbricas.}

De esta nueva modalidad han dado cuenta los medios de comunicación al hacerse eco de la posibilidad que ofrece la ONCE de elegir el número al que desea jugar una persona a través de un terminal electrónico ${ }^{63}$.

\section{Asignación y control del punto o zona de venta.}

\subsection{Asignación.}

A cada vendedor se le asigna un horario comercial de un punto o zona de venta para la realización de su jornada laboral. La asignación de puntos o zo-

${ }^{63}$ Vide diario El País de 10 de septiembre de 2004, "El cupón de la ONCE ya puede adquirirse "a la carta" a través de terminales móviles": «La Organización Nacional de Ciegos Españoles (ONCE) ha presentado de forma oficial el Terminal Punto de Venta (TPV), un sistema electrónico que utiliza las tecnologías móviles de última generación y que permite a los compradores del cupón elegir el número al que desean jugar. El Terminal Punto de Venta se está incorporando a la red de ventas de la ONCE de forma gradual, y actualmente son más de 6.000 unidades las que ya están en funcionamiento en toda España. 
nas de venta será competencia exclusiva de la dirección de los centros, a través del departamento de juego, sin que medie la suscripción de contrato alguno con los vendedores.

La asignación de los puntos de venta se determina en base a una serie de criterios objetivos $^{64}$. Además, atendiendo a las dificultades que tienen aquellos vendedores que son ciegos totales y trabajadores con grandes minusvalías, se les suele asignar un punto de venta cercano a su domicilio y que exijan la menor movilidad para su correcta explotación.

Este nuevo sistema de venta consta de un terminal portátil e inalámbrico por el que el vendedor se conecta, mediante tecnología móvil de última generación, con un ordenador central que facilita la posibilidad de elegir terminaciones o números completos de los cupones. Así, el cliente puede seleccionar el número que desea jugar. Una vez comprobado el número, el vendedor podrá imprimir de forma inmediata un ticket que tiene la misma garantía y validez que el cupón tradicional. Además, según ha señalado la propia organización, en el futuro será posible realizar el pago con tarjeta magnética o tarjeta chip.

El Terminal Punto de Venta, de un peso de 750 gramos y 21 centímetros de largo, está totalmente adaptado para que pueda ser manejado por personas ciegas o con otro tipo de discapacidades. El teclado es muy sencillo, parecido al de un teléfono móvil, cuenta con marcas táctiles, lleva una impresora de fácil carga de papel y, además, incorpora una voz sintetizada que puede graduarse en volumen y velocidad.

Asimismo, el TPV lleva incorporado un escáner que permite la comprobación de cupones premiados. Su alta tecnología permite a cada vendedor de la ONCE ejecutar las transacciones de venta, la devolución, el control de los cupones, la gestión y el pago de premios. El conversor textovoz permite oír los mensajes que reciben a través del terminal, mientras que éste se mantiene permanentemente conectado de forma segura al ordenador central de la ONCE a través de la red GPRS de Telefónica MoviStar en cualquier punto de España. Todos los vendedores de la ONCE están recibiendo unos cursillos para el manejo detallado de este nuevo dispositivo.

El desarrollo de estos Terminales Puntos de Venta ha sido posible gracias a la participación de tres compañías líderes: Gtech, líder mundial de sistemas de juego y de loterías; Ingénico, empresa número uno en ventas de TPV a nivel mundial, que ha diseñado este nuevo terminal con la tecnología más avanzada y la mayor seguridad; y Telefónica Móviles España, empresa pionera en tecnologías móviles de transmisión de datos sobre redes GMS/GPRS y UMTS. Mediante el Terminal Punto de Venta, el cupón de la ONCE se convierte en la primera lotería del mundo que se comercializa a través de terminales móviles con comunicaciones inalámbricas (GPRS)».

64 Vide STS de 26 de octubre de 1999 (Sala de lo Social), Ar. 7499, en el antecedente de hecho cuarto:

«En dicha Sentencia, se declararon probados los siguientes hechos: "I. La ONCE suscribió con la Sección Sindical de UGT, en fecha 25 de febrero de 1998, el IX Convenio Colectivo que fue publicado en el BOE de 24 de junio del último año, con vigencia hasta el 31-12-1998, cuyo ámbito abarca a todo el territorio del Estado Español. II. Los agentes vendedores de la ONCE con cierta antigüedad no tienen contrato escrito y sí los agentes de nuevo ingreso, cotizando todos ellos a la Seguridad Social como relación laboral de carácter especial en el grupo de cotización $5^{\circ}$. III. Los agentes-vendedores tienen asignado un lugar, puesto o zona concretos para realizar su trabajo de 
El XII Convenio Colectivo entre la empresa ONCE y sus trabajadores, art. 45, determina las reglas específicas de asignación-variación de puntos de venta a los agentes vendedores en los siguientes términos:

«1. Sin perjuicio del respeto a los derechos adquiridos por los agentes vendedores titulares de puntos de venta en los términos previstos en el art. 45.1 del XI Convenio Colectivo, la asignación de los puntos o zonas de venta a los vendedores será competencia exclusiva de las Direcciones de Centro, sin que medie la suscripción de contrato de titularidad de ningún tipo con los agentes vendedores. Dichas Direcciones establecerán las condiciones y obligaciones de los agentes vendedores sobre los puntos o zonas de venta que les sean asignados.

La asignación de un determinado punto o zona de venta no tendrá, por tanto, el carácter de derecho contractual del agente vendedor, ni supondrá la adquisición de titularidad o propiedad sobre el punto o zona de venta por su parte.

Consecuentemente, los puntos o zonas de venta tendrán la naturaleza o consideración de meros lugares de trabajo de los agentes vendedores a todos los efectos, pudiendo las Direcciones de Centro variar los puntos de venta asignados a los agentes vendedores en función de sus necesidades organizativas.

venta de cupones, habiéndose fijado en 40.000 pesetas el mínimo de venta diaria que deben efectuar. IV. Por Circular 2/1998, de 10 de marzo, la ONCE modificó algunas estrategias relativas a la comercialización de sus respectivos productos, a fin de buscar nuevos espacios de mercado o de asentar los ya existentes, así como la normativa reguladora de puntos de venta estableciendo, en las disposiciones 7.1 a) y 4.3 apartado b) que cuando el porcentaje de rentabilidad que se obtenga del punto de venta de un agente sea inferior al 70 por 100 durante un periodo superior a tres meses y esta baja rentabilidad sea atribuible a la deficiente explotación que realiza el vendedor, se puede revocar su titularidad, si está suficientemente demostrada la baja rentabilidad, proporcionándole otro punto de venta, previa instrucción del correspondiente expediente. V. Igualmente dispone dicha Circular 2/1998, en la disposición 5.1.5 apartados b) y f), que tienen la consideración de méritos a efectos de puntuación los siguientes supuestos:

Ceguera total: 25 puntos.

Ceguera parcial: 18 puntos.

Gran minusvalía: 18 puntos.

Cuando el agente opte a un quiosco, la ceguera total o parcial y además la sordera y/o amputación de una extremidad superior o inferior o parte esencial de la misma se valora de 1 a 7 puntos según lo concede la Junta Adjudicataria.

VI. La Comisión Paritaria del IX Convenio Colectivo, reunida el 30 de septiembre de 1998, a solicitud de CC.OO, interpretó, con el voto en contra de ésta, que la Circular 2/1998, de 10 de marzo, sobre adjudicación de puestos de venta, es válida y conforme al IX Convenio Colectivo». 
Si la variación produjera el cambio de residencia para el agente vendedor, será de aplicación lo previsto en los artículos 20 y 21 de este Convenio.

2. Los agentes vendedores actualmente titulares de puntos de venta podrán verse privados de su titularidad por las siguientes razones:

a) Por traslado voluntario o forzoso.

b) Por excedencia voluntaria.

c) Por aplicación del régimen disciplinario ante incumplimientos de sus deberes.

d) Por movilidad funcional.

e) Por concurrir circunstancias económicas, productivas, técnicas u organizativas, o por la necesidad de amortizar el punto de venta por causas legales o de mercado.

3. El punto de venta cuya titularidad haya sido perdida por un agente vendedor será cubierto, en su caso, mediante el sistema de asignación descrito en el punto 1 anterior.

4. Las Direcciones de Centro establecerán las condiciones de explotación de los puntos de venta ${ }^{65}$. Los agentes vendedores quedan comprometidos a explotarlos adecuadamente y a seguir las instrucciones que al respecto sean dictadas por las citadas Direcciones».

Mejorar las condiciones de la venta del cupón, y en especial de los vendedores, es el motivo que ha llevado a la ONCE a regular mediante circulares $^{66}$ esta modalidad de venta que inicialmente regentaba un sólo vendedor, pero que en la actualidad la suelen disfrutar dos o más, mediante turnos bien establecidos.

65 Vide Circular no 1/2002, de 2 de enero, reguladora de la creación y asignación de puntos o zonas de venta, apartado 5 , conceptos asociados a la productividad:

«Productividad de un centro o dependencia. Será el resultado de sumar todas las recaudaciones de los productos de carácter periódico habidas en un periodo determinado y dividirlo por la plantilla media existente en ese centro o dependencia en dicho periodo. Para hallar la plantilla media se dividirán las jornadas realizadas entre los días de sorteo.

Productividad de un vendedor. Será el resultado de sumar todas las ventas realizadas de productos de carácter periódico.

Productividad de un punto o zona de venta. Será el resultado de sumar todas las ventas de productos de carácter periódico realizadas por los vendedores que ejercen la venta en el mismo.

Porcentaje de productividad. Es aquél que alcanza un vendedor, punto o zona de venta, en cómputo mensual o espacio superior de tiempo con respecto a la productividad de un centro o dependencia. Es decir el resultante de realizar la siguiente operación: productividad del vendedor, punto o zona de venta menos productividad del centro o dependencia dividido por la productividad del centro o dependencia y multiplicado por 100 ».

66 Vide Jesús MONTORO MARTÍNEZ, Los ciegos en la historia, Tomo V, o.c., p. 146, donde se- 
En el caso de aquellos vendedores que tengan asignado un punto o zona de venta y durante el último año hayan obtenido una rentabilidad por encima de la media del centro, para poder revocarle dicha asignación, previamente deberá ser puesto en conocimiento del vendedor, y la decisión final deberá ser tomada por una comisión constituida a tal efecto en todas las Delegaciones Territoriales y Direcciones Administrativas. Dicha comisión será presidida por el jefe de centro y estará constituida además por el jefe del departamento de juego, director de agencia cuando el vendedor esté adscrito a una agencia, especialista de ventas del área donde se encuentra ubicado el punto de venta, miembro del comité de empresa del centro al que esté adscrito dicho vendedor y un consejero territorial.

Las asignaciones se realizarán en función del perfil del vendedor y su adecuación a las necesidades comerciales a cubrir. La dirección de los centros establecerán las condiciones y obligaciones de los vendedores respecto a los horarios de los puntos o zonas de venta que les sean asignados. Tanto la asignación, como la modificación del punto o zona de venta, del horario comercial, de la zona de influencia del punto de venta y demás consideraciones sobre el particular, se realizará por escrito. Todos los vendedores deberán tener asignado un punto o zona de venta donde ejercer su actividad laboral.

\subsection{Control.}

Para poder realizar un eficaz control y seguimiento de las variaciones de todos los puntos o zonas de venta, se contará con el carné de vendedor y la aplicación informática establecida para la gestión comercial de la red de ventas, debiendo estar en todo momento actualizados sus datos.

ñala: «La normativa sobre los quioscos de la Corporación para la venta de su cupón está contenida principalmente en las circulares no 186, de 29 de marzo de 1946, y 223 del 19 de junio de 1948, en el Apartado c) del Oficio-Circular del 27 de enero de 1950 y, recientemente en la Circular $n^{\circ} 20$ del 22 de septiembre de 1993, cuyo asunto es normativa reguladora sobre puntos y puestos de venta que concreta la creación, adjudicación, explotación y extinción de los diferentes puntos de venta del cupón de la ONCE, derogándose la Circular no 24 de 14 de septiembre de 1989 ».

En la actualidad es la Circular nº 1/2002, de 2 de enero, la que regula la creación y asignación de puntos o zonas de venta. 


\subsubsection{Carné de vendedor.}

Cada vendedor dispondrá de un carné ${ }^{67}$, facilitado por la Dirección General, el cual deberá llevar consigo siempre que esté realizando la venta.

Cada vendedor deberá llevar en sitio visible una identificación homologada por la ONCE durante el tiempo en que desarrolle el ejercicio de la venta.

\subsubsection{Aplicación informática.}

La aplicación informática establecida para la gestión comercial de la red de ventas es la herramienta de control de los puntos o zonas de venta así como de los vendedores que ejercen la venta en los mismos y figurarán, entre otros datos, los siguientes: a) Un número secuencial para cada uno de los puntos o zonas de venta. b) Centro, municipio principal, núcleo, distrito y barrio al que pertenece el punto o zona de venta. c) Vendedores asignados a cada punto o zona de venta. d) Equipamiento. e) Fecha de creación. f) Estado de conservación. g) Horario comercial. h) Horario comercial del vendedor asignado a un punto o zona de venta. i) Productividad del punto o zona de venta. j) Días en los que el punto o zona de venta permanece activo.

$\mathrm{Y}$ todos aquellos datos que sean relevantes para un mejor conocimiento del punto o zona de venta, o de los vendedores.

\section{Creación de puntos de venta fijos para la comercialización de los juegos: quioscos y stands ${ }^{68}$.}

\subsection{Requisitos para la instalación de quioscos y stands.}

\footnotetext{
${ }^{67}$ En este carné figurarán los siguientes datos: a) En el anverso (DNI.; Código único de persona; Nombre y apellidos; Fotografía). b) En el reverso, además de la banda magnética grabada con los datos necesarios relativos al vendedor y que servirá para realizar determinadas operaciones de devolución, liquidación, etc., llevará una etiqueta adherida en la que se hará constar: código de centro correspondiente a la dependencia donde esté adscrito el vendedor; municipio donde realiza la venta; puntos o zona de venta asignado especificando su tipología (puesto de venta, área de venta, quiosco, stand, local comercial y ruta de venta); horario comercial asignado.

68 Vide Redacción (Consultas), "Ocupación de la vía pública con quiosco de la ONCE”, Actualidad Administrativa, 2, (2005), pp. 230-231.
} 
Para la ubicación de un quiosco en un puesto de venta será necesario que el puesto de venta en el que se vaya a instalar haya alcanzado de forma estable, a lo largo de un período mínimo de seis meses, la productividad requerida para dicha instalación, según el baremo establecido en cada momento por la Dirección General ${ }^{69}$. Dicho baremo es actualizado periódicamente según las variaciones que se produzcan tanto en el aspecto de la productividad como de los costes del punto o zona de venta.

La ONCE tiene entre sus objetivos la consecución del máximo número de puntos de venta cerrados (quioscos). En aquellos lugares en que por las características urbanísticas esto no fuera posible, los vendedores podrán utilizar exclusivamente, los expositores portátiles homologados por la ONCE.

\subsection{Estudios para el análisis y creación de puntos o zonas de venta.}

El departamento de juego realizará periódicamente los pertinentes estudios pormenorizados de todos y cada uno de los puntos de venta, rutas comerciales y zonas de venta, incluidos lo que están situados en grandes superficies comerciales, almacenes, o cualquier otro complejo, con el fin de evaluar permanentemente sus potencialidades comerciales y proceder en consecuencia a la fijación, o modificación, de los correspondientes horarios de explotación.

Los especialistas de ventas realizarán un trabajo sistemático de detección de nuevos puntos o zonas de venta, no sólo en la vía pública, sino en centros comerciales, estaciones de ferrocarril y metropolitano, o en cualquier otro ámbito donde se produzca actividad comercial.

Para que un punto o zona de venta sea homologado como tal deberá alcanzar una productividad equivalente al mínimo mensual de ventas, que en cada momento esté vigente en el convenio colectivo, considerando las jornadas que entren en el período de prueba.

En la aplicación informática establecida para la gestión comercial de la red de ventas deben figurar todos los puntos o zonas de venta detectados por la unidad técnica comercial, estén homologados o no.

${ }^{69}$ Sobre el número total de quioscos de la ONCE Vide ONCE, 65 años de historia, ONCE, Madrid, 2004, p. 87: «En 1980 hay 1.350 instalados en todo el país. 500 en Madrid, 450 en Barcelona y 400 en el resto de las provincias con Delegaciones de la ONCE». La ONCE, con fecha 29 de noviembre de 2005, me facilita la siguiente información: «Número de quioscos y stands existentes en todo el territorio nacional: 8.335. Por autonomías (Cataluña: 2.649. Andalucía: 1.648. Madrid: 1.323. Valencia: 789). Por localidades (Madrid: 791. Barcelona: 719. Valencia: 296)». 


\section{La ubicación de puntos de venta fijos (quioscos de la ONCE) en el domi- nio público ${ }^{70}$.}

El hecho de ejercer en la calle está configurado por un gran número de connotaciones, en gran medida negativas, que se veían reforzadas en el caso de la ONCE por ser la persona afectada un discapacitado. La calle es un espacio cargado de provisionalidad e incluso de marginalidad, valores que contaminan a las personas que ejercen su labor o desempeñan alguna actividad en dicho espacio. Por todo ello, una iniciativa de gran trascendencia en la dignificación de los vendedores del cupón ha sido el cambio que han experimentado en la escenografía urbana, con la progresiva implantación de quioscos, y que además de ejercer varios papeles funcionales, también representan otros simbólicos.

Sin duda, lo que pretendía la ONCE era proporcionar a sus vendedores un lugar más cómodo en donde desempeñar su labor comercial, al abrigo de las inclemencias del tiempo. También se consigue que desde el punto de vista de la comunicación, los quioscos figuran como espacios físicos de publicidad estática al ubicar el logo de la ONCE en emplazamientos estratégicos ${ }^{71}$.

\section{La ubicación de puntos de venta fijos en centros comerciales.}

A los efectos de la instalación de un punto de venta fijo en un centro comercial (stand), se entiende por los mismos, no sólo los hipermercados o ga-

${ }^{70}$ Vide Redacción (Consultas), "Ocupación de la vía pública con quiosco de la ONCE”, Actualidad Administrativa, 2, (2005), pp. 230-231.

${ }^{71}$ Vide Antón ALVAREZ RUIZ, La función social de la publicidad de la ONCE, Escuela Libre Editorial, Madrid, 2003, pp. 163-166: «Pero antes debemos realizar una precisión. Actualmente sólo uno de cada tres vendedores del cupón realiza su trabajo desde un quiosco. No tendría lógica comercial ubicar a todos los vendedores en quioscos, porque hay zonas que se cubren mucho mejor con el sistema de venta ambulante, y prescindir de ésta supondría perder una cuota de mercado realmente importante. Pero aún así, el cambio de imagen, la dignificación laboral y otros aspectos que vamos a comentar, sobrevenidos como consecuencia de la implantación de los quios$\cos$, han afectado positivamente a toda la red de vendedores, incluidos aquellos que siguen realizando su trabajo de forma itinerante».

Además señala los siguientes aspectos positivos: la instalación de quioscos elimina los elementos de provisionalidad; el quiosco invierte los términos en los que se realiza el intercambio comercial del cupón; supone un refuerzo de la percepción de los vendedores como profesionales del sector terciario; facilitan el trato entre personas discapacitadas y no discapacitadas; para el vendedor constituye un símbolo de autoafirmación». 
lerías comerciales, sino también estaciones de ferrocarril, de metropolitano, o cualquier otro lugar en el que exista actividad comercial para la venta del cupón y demás juegos autorizados para su comercialización por la ONCE.

Cuando una cadena de centros comerciales tiene implantación en todo el territorio del Estado, o supera el ámbito de actuación de más de una Delegación Territorial o Dirección Administrativa, corresponde a la Dirección General la obtención de un acuerdo con la misma para realizar la venta de los productos y, siempre que sea posible, con un stand o expositor. Ello con el fin de evitar la disparidad, tanto en los alquileres a abonar como en otras condiciones contractuales.

Una vez alcanzado el acuerdo por parte de la Dirección General, ésta remitirá a todos los centros comunicación en tal sentido. En ella se indicarán los aspectos de más interés, tales como las condiciones económicas, duración, etc., remitiendo a aquellas Delegaciones Territoriales o Direcciones Administrativas afectadas por la firma del acuerdo, copia del contrato y del anexo correspondiente.

La negociación de los acuerdos con centros comerciales de ámbito autonómico o local corresponderá a las Delegaciones Territoriales o Direcciones Administrativas. En dichas negociaciones, deberán ajustarse en todo momento al baremo sobre pago de alquileres que establece la Dirección de Planificación de Juego, no pudiendo firmar contrato alguno que no se ajuste a dicho baremos, sin previa consulta a la Dirección General.

Si es posible, antes de la firma de un contrato con un centro comercial, se realizará un periodo de prueba con el fin de determinar la rentabilidad real que se alcanza en un punto o zona de venta. Si el período de prueba fuese totalmente imposible, se suele fijar en el contrato un periodo de prueba mínimo de tres meses para comprobar la rentabilidad real del punto, contemplándose en el contrato la posibilidad de la rescisión del mismo en el supuesto de que la prueba no sea satisfactoria. 